\title{
Polymyxins and Bacterial Membranes: A Review of Antibacterial Activity and Mechanisms of Resistance
}

\author{
Carole Ayoub Moubareck (1) \\ College of Natural and Health Sciences, Zayed University, Dubai 19282, UAE; \\ Carole.AyoubMoubareck@zu.ac.ae; Tel.: +971-4402-1745
}

Received: 27 June 2020; Accepted: 31 July 2020; Published: 8 August 2020

\begin{abstract}
Following their initial discovery in the 1940s, polymyxin antibiotics fell into disfavor due to their potential clinical toxicity, especially nephrotoxicity. However, the dry antibiotic development pipeline, together with the rising global prevalence of infections caused by multidrug-resistant (MDR) Gram-negative bacteria have both rejuvenated clinical interest in these polypeptide antibiotics. Parallel to the revival of their use, investigations into the mechanisms of action and resistance to polymyxins have intensified. With an initial known effect on biological membranes, research has uncovered the detailed molecular and chemical interactions that polymyxins have with Gram-negative outer membranes and lipopolysaccharide structure. In addition, genetic and epidemiological studies have revealed the basis of resistance to these agents. Nowadays, resistance to polymyxins in MDR Gram-negative pathogens is well elucidated, with chromosomal as well as plasmid-encoded, transferrable pathways. The aims of the current review are to highlight the important chemical, microbiological, and pharmacological properties of polymyxins, to discuss their mechanistic effects on bacterial membranes, and to revise the current knowledge about Gram-negative acquired resistance to these agents. Finally, recent research, directed towards new perspectives for improving these old agents utilized in the 21st century, to combat drug-resistant pathogens, is summarized.
\end{abstract}

Keywords: polymyxins; colistin; outer membrane; lipopolysaccharide; $m c r$; antibiotic resistance; Gram-negative pathogens

\section{Introduction}

The progressive global rise and dissemination of multidrug-resistant (MDR) bacteria represent an enormous threat to humans today, and a main concern to public health and modern health care systems [1]. Given their distinctive cellular features, Gram-negative bacteria are said to specifically develop and acquire dynamic resistance patterns and cause significant morbidity and mortality worldwide. Among these, carbapenem-resistant Enterobacteriaceae, MDR Pseudomonas aeruginosa, and MDR Acinetobacter baumannii represent serious pressures to antimicrobial therapy, due to the extremely limited efficacious treatment options [2]. Against such pathogens, polymyxins represent one of the last-resort antibiotics that is still effective [3], among few others, including fosfomycin, ceftazidime/avibactam and the recently approved meropenem-vaborbactam $[4,5]$. Polymyxins have recently been invigorated as a class of bactericidal drugs that disrupt the outer cell membrane, and with their revival, studies to understand their effects on bacterial cells were also actively restarted [6]. Nevertheless, the utility of polymyxins is currently facing a worldwide increasing resistance, particularly due to the plasmid-encoded mobilized colistin resistance $(\mathrm{mcr})$ gene present in pathogens such as Escherichia coli and Klebsiella pneumoniae [7]. Polymyxins are definitely relevant in the context of biological membranes study, since the Gram-negative outer membrane represents their first and foremost target. In this paper, the main properties, mechanism of action, resistance pathways, and forthcoming clinical and research directions for polymyxins are reviewed. 


\section{Historical Background and Types of Polymyxins}

The polymyxins comprise a group of old antimicrobial substances that are nonribosomal cyclic lipopeptide, secondary metabolites of the soil, marine, and plant bacterium Paenibacillus polymyxa [8]. Formerly known as Bacillus polymyxa var. colistinus, this aerobic, Gram-positive, spore-forming organism was the source of colistin (also known as polymyxin E), originally discovered in 1947 by Benedict and Langlykke [9]. Four additional polymyxins, named A to D, were recovered from the metabolism fluid of different strains of P. polymyxa $[10,11]$. Polymyxin A was formerly called "Aerosporin" and polymyxin D "Polymyxin." All polymyxins are cationic decapeptides, consisting of a cyclic heptapeptide linked to a linear tripeptide side chain acylated at the $\mathrm{N}$ terminus by a fatty acid tail [12]. A common property of polymyxins is including L- $\alpha, \gamma$-diaminobutyric acid (Dab), the amino acid threonine, and a branched fatty acid in their structure. They differ in their amino acid composition, where all except polymyxin $C$ contain leucine, polymyxins $B$ and $C$ contain phenylalanine, and only polymyxin D contains serine [11,12]. The structures of polymyxin B and colistin are shown and compared in Figure 1. The differences between the various polymyxin components, namely polymyxins B1, B2, E1, and E2 and colistimethate, are also shown and described shortly (Section 3).

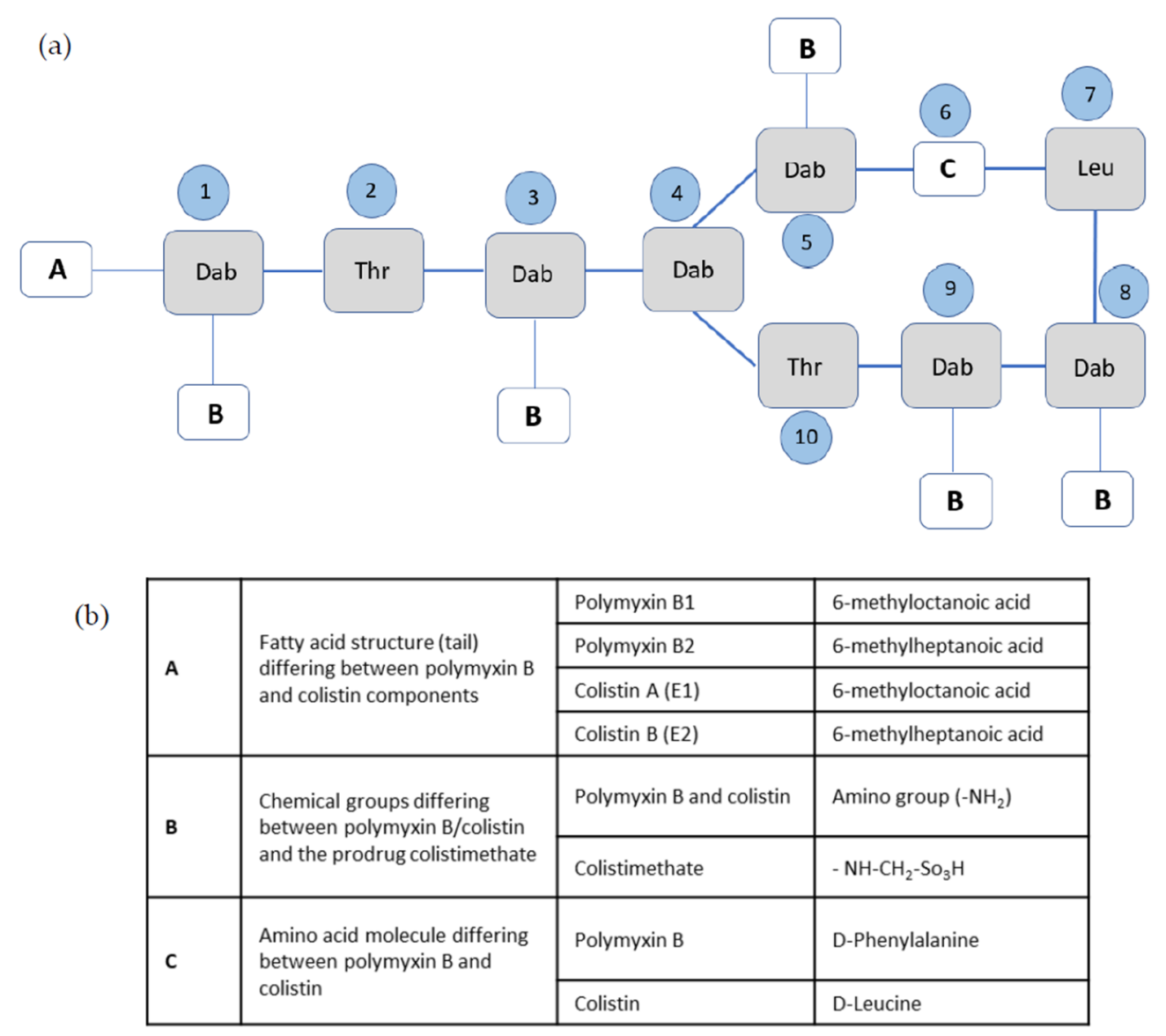

Figure 1. (a) Representation of the chemical structures of polymyxin B and colistin, with components B1, B2, E1, and E2, as well as colistimethate. The shaded boxes represent the fixed portions of the molecule, while the white boxes represent the structures that differ among polymyxin B, colistin, and/or colistimethate. The numbers in the blue circles correspond to the numbering of the amino acids from 1 to 10. The linear part of the molecule consists of a tripeptide (amino acids 1-3), while the cyclic part consists of a heptapeptide (amino acids $4-10$ ). Dab $=\mathrm{L}-\alpha, \gamma$-diaminobutyric acid, Thr $=$ Threonine; Leu = Leucine. (b) The groups A, B, and C in section (a) are described, and they represent the chemical moieties with variation between the polymyxins B1, B2, E1, E2 or between them and the prodrug colistimethate. 
Of all five polymyxins, only polymyxin B and colistin were put into clinical use in the 1950s, as they were found to be the least nephrotoxic. Eventually, these antibiotics fell out of favor and their systemic use waned due to their significant adverse effects, especially their potential for nephrotoxicity and neurotoxicity [12,13]. Early medicinal chemistry efforts with polymyxins in the 1970s aimed at modifying their structures to improve their safety. However, the majority of these trials were limited to modifications to the peripheries of the polymyxin structure, namely the acylation/alkylation of the side-chain amino groups of the Dab residue, or the substitution of the N-terminal fatty acyl chain [8]. At that time, the lack of robust synthetic platforms that allow the total synthesis of polymyxin lipopeptides, as well as the limited understanding of polymyxin pharmacology, were a barrier to obtain more tolerable and effective compounds [13], and their clinical use dramatically declined [14]. This was concurrent with the emergence of less-toxic aminoglycosides and other antipseudomonal agents [15]. Nevertheless, interest in polymyxin B and colistin has risen substantially in the last two decades, with the emergence of MDR Gram-negative organisms nonresponsive to other clinically available antibiotics [16,17]. In this review, and unless otherwise indicated, the term polymyxins shall be used to refer to the two clinically useful compounds, polymyxin B and colistin.

\section{Clinically Useful Polymyxins and Their Principle Properties}

Despite minor differences, polymyxin B and colistin have comparable chemical structures, mechanisms of action, and spectra of activity. However, they have different pharmacokinetics and pharmacodynamics. The sections below address the essential properties of the two clinically useful compounds.

\subsection{Chemical Properties and Structure-Activity Relationships}

Colistin and polymyxin B differ by a single amino acid at position 6 in the peptide ring, as shown in Figure 1, with a D-phenylalanine in polymyxin B and a D-leucine in colistin [18]. Both drugs are highly basic due to five free amino groups [19]. Polymyxin B is primarily composed of a mixture of two polypeptides, polymyxin B1 and polymyxin B2; colistin is primarily composed of a mixture of colistin A (also known as polymyxin E1) and colistin B (also known as polymyxin E2). The difference between these four compounds is the fatty acid substitution of the lipopeptide structure, where it consists of 6-methyloctanoic acid in polymyxins B1 and E1, and of 6-methylheptanoic acid in polymyxins B2 and E2 (Figure 1) [20].

Although the mechanistic action of polymyxin B and colistin shall be deliberated exquisitely later in this review, it is important to mention, in context of their structure, that their chemistry is critical to their antibacterial activity [18]. The primary amines of the Dab residues are ionized at physiological $\mathrm{pH}$, allowing the polymyxin molecules to carry a net polycationic charge, a vital characteristic for their interaction with negatively charged phosphate groups of the lipid A of bacterial lipopolysaccharide (LPS). In addition, polymyxins possess hydrophobic domains, namely the fatty acyl side chain, and these are able to interact with corresponding LPS structures [21]. Therefore, as a result of such assembly of hydrophilic and lipophilic entities, polymyxins are amphipathic and capable of both ionic and hydrophobic molecular interactions at the bacterial outer membrane level, contributing to their mechanism of action [13]. Studies from models using monolayers of LPS of Gram-negative bacteria indicate that chemical cationic amphipathicity determines polymyxin activity [22].

A deep understanding of the structure-activity relationships of polymyxins has been established, including the capacity of their three-dimensional structure to interact with bacterial membranes [23]. Polymyxins initially act by binding to lipid A of LPS, whose anionic nature facilitates the electrostatic interaction with the cationic polymyxins. This primary interaction leads to the disruption of bacterial outer membrane and the hydrophobic insertion of the fatty acyl chain of polymyxin into lipid A. Subsequently, cytoplasmic membrane disruption and the potential additional intracellular interactions lead to cell death [24]. Important contributions were made by the N-terminal fatty acyl chain of polymyxins to binding with LPS and consequent antibacterial activity. A comparison across 
different N-terminal fatty acyl chains documented that antimicrobial activity correlated with the length and bulkiness of the $\mathrm{N}$-terminal fatty acid, where seven to nine carbon atoms are optimal for binding affinity [13].

Another important structural feature of the polymyxins, vital for their activity, is the presence of multiple positively charged Dab side chains, which interact with the phosphate groups on lipid A [8]. The key features of the Dab residues that are important for LPS binding affinity include the cationic character, the two methylene groups of the Dab side chain, and the characteristic order of the Dab residues within the primary polymyxin sequence that confers the proper spatial distribution of the positive charges for electrostatic interactions with the phosphates of lipid A. Overall, the Dab residues, particularly those lying within the cyclic heptapeptide, are indispensable for antimicrobial activity $[13,25]$. Furthermore, polymyxins contain D-phenylalanine and L-leucine at the amino acid positions 6 and 7, respectively, in the fatty acid chain of polymyxin B, and D-leucine and L-leucine at positions 6 and 7, respectively, in colistin, within the heptapeptide ring. These amino acids ensure a hydrophobic motif believed to insert into the bacterial outer membrane and stabilize LPS complexation, via hydrophobic interactions with the fatty acyl chains of lipid A [26]. Finally, the particular combination of topographic chemical features and the special configuration of the polymyxin ring structure appears ideal for efficient binding to LPS and the subsequent membrane permeabilizing effect. Previous attempts to produce an extended ring structure, generated by the insertion of additional Dab residues, yielded resultant compounds that were significantly less active than polymyxins [27].

\subsection{Spectrum of Antibacterial Activity}

Polymyxins demonstrate important activity against Gram-negative aerobic pathogens, including most members of the Enterobacteriaceae family, E. coli, Enterobacter spp., Klebsiella spp., Citrobacter spp., Salmonella spp., and Shigella spp [12]. Additionally, they are effective against non-fermentative Gram-negative common pathogens, including A. baumannii and P. aeruginosa. The breakpoints of sensitivity for Enterobacteriaceae, Pseudomonas, and Acinetobacter according to the 2020 internationally adopted guidelines are shown in Table 1 [28,29]. These breakpoints correspond to the minimum inhibitory concentration (MIC) used to categorize strains as sensitive, resistant, or intermediate in their response to polymyxins. In vitro susceptibility was reported for Stenotrophomonas maltophilia [30]. Notable exceptions of Gram-negative bacteria that are naturally resistant to polymyxins comprise Pseudomonas mallei, Morganella morganii, Vibrio cholerae, Serratia marcescens, Proteus spp., Providencia spp., Burkholderia cepacia, Chromobacterium spp., Edwardsiella spp., Brucella, Legionella, and Campylobacter. Polymyxins are not active against Gram-negative cocci (such as Neisseria spp.), nor against Gram-positive and anaerobic bacteria, parasites or fungi [31].

Table 1. Minimum inhibitory concentration (MIC) breakpoints of colistin sensitivity according to the European Committee on Antimicrobial Susceptibility Testing (EUCAST) and of colistin/polymyxin B sensitivity according to Clinical Laboratory and Standards Institute (CLSI).

\begin{tabular}{lcccc}
\hline & EUCAST Breakpoints (mg/L) & \multicolumn{2}{c}{ CLSI Breakpoints } \\
\hline & $\mathrm{S} \leq$ & $\mathrm{R}>$ & $\mathrm{I} \leq$ & $\mathrm{R} \geq$ \\
\hline Enterobacteriaceae & 2 & 2 & 2 & 4 \\
Pseudomonas & 2 & 2 & 2 & 4 \\
Acinetobacter & 2 & 2 & 2 & 4 \\
\hline \multicolumn{5}{c}{$\mathrm{S}=$ sensitive; $\mathrm{R}=$ resistant; I = Intermediate. }
\end{tabular}

Modifications in lipid A of LPS are associated with the innate resistance seen in bacteria intrinsically resistant to polymyxins [32]. For example, in Proteus mirabilis, the expression of a seven-gene operon, called the pmrHFIJKLM homologue, is involved in LPS modification, leading to polymyxin resistance [33]. In Brucella melitensis, lowering the phosphoethanolamine (pEtN) content of the cell envelope, using the enzyme BveA, a type of phospholipase, increases B. melitensis resistance to 
polymyxin B [34]. Conversely, in Campylobacter jejuni, modifying lipid A by the addition of pEtN, using the catalytic action of the enzyme $\mathrm{pEtN}$ transferase, promotes polymyxin resistance [35]. Nevertheless, recent research on the in vitro activity of colistin against $C$. jejuni and Campylobacter coli, obtained from fecal material of patients with severe diarrhea, have shown low inhibitory values [36]. The question whether colistin may represent an alternative to fluoroquinolones and tetracyclines for the treatment of severe diarrhea produced by these species warrants additional investigation.

\subsection{Administration and Clinical Uses}

Polymyxin B and colistin harbor different modes of administration to maintain activity [37]. Polymyxin B is administered as the active antibacterial compound, polymyxin B sulfate, which is given intravenously. Polymyxin B is not absorbed from the gastrointestinal tract. Topical, nonabsorbable oral, and ophthalmic formulations are available. Additional routes of administration include inhaled and intrathecal administration [38].

In contrast, colistin is administered parenterally as a prodrug, colistin methanesulfonate, also named colistimethate sodium (CMS), which is considered less toxic than the parent drug, colistin sulfate, upon parenteral administration [39]. CMS itself lacks intrinsic antibacterial activity; it should be converted in vivo into colistin after its administration [18,40]. In chemical synthesis, CMS is produced via an interaction of colistin with formaldehyde and sodium bisulfite, leading to a sulfomethyl group being added to the primary amines of colistin [41]. As such, colistin and CMS also differ in administration: Colistin is primarily used topically, whereas CMS is used parenterally, and both may be given by inhalation [42].

\subsubsection{Systemic Use}

Due to their poor oral absorption, orally administered polymyxins are only used for digestive tract disinfection. Moreover, polymyxins do not efficiently diffuse into tissues, neither do they penetrate the cerebrospinal fluid, nor the pleural and peritoneal cavities [43]. Nevertheless, polymyxins are used systemically by intravenous administration for serious infections due to pathogens resistant to other effective therapies. They are indicated for the treatment of diverse infections, including pneumonia, bacteremia, urinary tract infections, bone and joint infections, burn infections, endocarditis, cellulitis, cystic fibrosis, gynecologic infections, meningitis, and ventriculitis [44]. Whether polymyxin B or colistin are preferable for systemic administration is debatable. Some trials suggest that polymyxin $\mathrm{B}$ achieves adequate drug levels more rapidly and reliably than colistin, the latter being a prodrug. An exception may be infections of the urinary tract, where colistin appears to be more effective and reaches high urinary levels, probably due to the extrarenal clearance of polymyxin B, keeping its urinary concentrations low $[18,45]$. Inhaled forms of both polymyxin B and colistin are available, and are given via a nebulizer to reach the lungs for the management of chronic pneumonia caused by $\mathrm{P}$. aeruginosa in cystic fibrosis patients. However, because polymyxin B is more likely to cause airway obstruction, colistin is generally preferred for this indication [46]. The intrathecal and intraventricular administration of either polymyxin B or colistin is useful for central nervous system infections due to MDR Gram-negative bacteria, as an adjunct to systemic antibiotic therapy. As for the inhaled route, clinical experience, safety, and efficacy appear to be higher for intrathecal and intraventricular colistin, while experience with polymyxin B via these routes is limited [47].

\subsubsection{Topical Use}

Polymyxin B sulfate is available for ophthalmic, otic, and topical use in combination with a variety of other compounds, while colistin is available as otic drops [48]. Polymyxin B is used with bacitracin as an opthalmic ointment, while it is available with neomycin as a urinary bladder irrigant for short-term use (up to 10 days) in abacteriuric patients to help prevent bacteriuria and Gram-negative rod septicemia associated with the use of indwelling catheters. It is also available with both bacitracin and neomycin as a topical antibiotic [49]. Infections of the skin, mucous membranes, eye, and ear due 
to sensitive microorganisms respond to the local application of polymyxin B in solution or ointment form. External otitis, frequently due to Pseudomonas, may also be cured by the topical use of the drug. $P$. aeruginosa is a common cause of infection of corneal ulcers; the local application or subconjunctival injection of polymyxin B is often curative [50].

\subsection{Pharmacokinetics}

Polymyxin B is administered directly in its active antibacterial form, and is subject to very extensive renal tubular reabsorption and thus primarily undergoes nonrenal clearance. Pharmacokinetic data on polymyxin B are limited. Over 95\% of polymyxin B is cleared independently of the kidneys. Little is known about its extravascular distribution or penetration into other tissues, but it is thought to be similar to that of colistin, with generally poor penetration into the lungs, pleura, bones, and central nervous system [38].

Unlike polymyxin B, and following parenteral administration, about 20-25\% of the dose of CMS prodrug is hydrolyzed in vivo into an active colistin entity, while a large proportion of the prodrug is eliminated mainly through the kidneys by glomerular filtration and tubular secretion [51]. CMS (but not colistin) is cleared renally; thus, the modification of the dose is generally required in patients with impaired renal function. Therefore, colistin concentrations resulting from the original CMS administration are low. In contrast to CMS, colistin is eliminated predominantly by nonrenal pathways because of its extensive renal tubular reabsorption. Although colistin is poorly excreted in urine, the urinary concentration of colistin may be relatively high after the administration of CMS, since the conversion of most colistin recovered in the urine is from the post-excretion hydrolysis of CMS into colistin within the urinary tract [12]. Colistin is tightly bound to membrane lipids of the cells in many body tissues, including the liver, lung, kidney, brain, heart, and muscles. The half life of colistin following IV administration is about 2-3 hours in subjects with normal renal function, and it is about $50 \%$ protein bound [37].

\subsection{Toxicity}

Perhaps the most common and clinically significant adverse effect of intravenous polymyxins is nephrotoxicity, which has an incidence of $50-60 \%$ in patients receiving polymyxin B or colistin [52], with expert opinion suggesting that the relative risk of nephrotoxicity is not significantly different among the two compounds [53]. Polymyxins have correlations with hematuria, proteinuria, oliguria, and acute kidney injury. Therefore, renal function should be monitored closely during administration, and the concurrent use of other nephrotoxic drugs should be avoided whenever possible [54]. The plasma concentrations of polymyxins associated with the increased risk of acute renal failure intersect with those required for antibacterial effect, rendering these drugs of narrow therapeutic index, a quantitative measurement of the relative safety of a drug that compares the amount that causes the therapeutic effect to the amount that causes toxicity [55]. The requirement for the conversion and recycling of polymyxins in the kidneys, as described above, makes the proximal tubular cells of the kidney the major location where polymyxins accumulate, while their concentrations are much lower in the liver, heart, lungs, spleen, and muscles [56]. Cell line investigations and in vivo preclinical models studying polymyxins toxicity on renal tubular cells suggest several cellular mechanisms. These include oxidative stress, apoptosis, cell cycle arrest, and autophagy [57]. The nephrotoxic potential of polymyxins is associated with their chemical structure. Attempts for the complete removal of the N-terminal fatty acyl group, considered a nephrotoxicity "hot-spot", or to decrease its hydrophobicity, thereby reducing its uptake by renal tubular cells, produced derivatives with reduced nephrotoxicity. However, this occurred at the expense of significantly reduced antibacterial activity compared with polymyxin B and colistin [8].

Added to nephrotoxicity, hypersensitivity reactions, manifested as rash, pruritus, urticaria, and fever have been reported with the systemic use of polymyxins, [54], as well as neurotoxicity, seen in about $7 \%$ of patients. The latter is clinically characterized by symptoms of dizziness, visual disturbance, ataxia, vertigo, confusion, hallucinations, seizures, and facial and peripheral paresthesias. The use of 
other neurotoxic drugs concomitantly should be avoided [58]. It is believed that such manifestations result from the injury and death of neuronal cells, largely caused by reactive oxygen-induced oxidative stress and mitochondrial dysfunction, followed by apoptosis and autophagy [59,60]. Experimental trials for the scavenging of reactive species and halting apoptosis in cell lines using certain agents claimed to be neuroprotective, such as minocycline and rapamycin, are underway $[59,61,62]$. Finally, apart from the above adverse effects and in some reports, skin hyperpigmentation was documented with intravenous polymyxin B, and was associated with melanocyte activation and inflammatory process in the skin $[63,64]$.

\section{Mechanism of Action of Polymyxins and Proposed Interactions with Bacterial Membranes and Other Cellular Structures}

\subsection{Overview}

The study of mechanistic pathways used by polymyxins to kill Gram-negative bacteria has been the subject of extensive research. The expanding interest in the use of these antibiotics with a focus on their mechanism of antibacterial activity, and the subsequently emerging resistance in Gram-negative bacteria, has been nicely described in previous reviews [12,65]. Even though the details of the antibacterial activity of these compounds are yet to be thoroughly understood, their initial interaction with bacterial membranes is indispensable [21]. In this context, polymyxins, basic peptides with a molecular weight of about $1000 \mathrm{Da}$, act as surface-active amphipathic agents or cationic detergents. They interact strongly with phospholipids and disrupt the structure of cell membranes. Specifically, polymyxins bind to LPS and phospholipids in the outer cell membrane of Gram-negative bacteria. They competitively displace divalent cations from the phosphate groups of membrane lipids, which leads to the destabilization of the outer cell membrane, the leakage of intracellular contents, and bacterial cell death [66].

To properly comprehend the mechanism of action of polymyxins, an understanding of the outer membrane structure in Gram-negative bacteria is imperative. This membrane surrounds a thin peptidoglycan layer, and comprises an exclusive architecture, not found in Gram-positive bacteria [67]. Its structure allows it to be a potent selective permeability barrier against harmful molecules, such as detergents antibiotics [68]. The outer membrane organization and the binding of polymyxins are shown in Figure 2.

The chemical composition of the outer membrane is heterogeneous, with phospholipids, LPS, outer membrane proteins, and lipoproteins [69]. Such a blend of chemical components is arranged asymmetrically, where a bilayer of phospholipids, similar to other biological membranes, exists in the inner leaflet, and LPS in the outer leaflet, with anchored lipoproteins and outer membrane proteins [70]. Phospholipids of the outer membrane include different molecules, such as phophatidylethanolamine, phosphatidylglycerol, and cardiolipin [70]. Regarding the outer membrane anchored lipoproteins, these play a key role in the linkage between the outer membrane and peptidoglycan, peptidoglycan biosynthesis, flagellar assembly, and protein secretion and polysaccharide secretion [68,71]. Outer membrane proteins act as porins, specific and non-specific channels that regulate the transport of hydrophilic molecules across the outer membrane [72]. On the other hand, the LPS is a complex, glucosamine-based glycolipid unique to Gram-negative bacteria. It is composed of lipid A, core oligosaccharide, and O-antigen polysaccharide chains, and plays a critical role in the barrier function of the outer membrane [73]. Lipid A (endotoxin) is a powerful stimulator of human immune response, and is released upon bacterial death, resulting in the secretion of a number of proinflammatory cytokines from monocytes and macrophages, with the resulting possibility of Gram-negative sepsis [74,75]. The chemical structure of lipid A consists of D-glucosamine disaccharide that is phosphorylated at the $1^{\prime}$ - and $4^{\prime}$ positions, with fatty acid esters attached to both carbohydrates. The fatty acyl chain length may vary between bacterial species, but is typically conserved within a given species. The lipid A chains are tightly packed together within the outer membrane through van der Waals forces, while divalent calcium and magnesium cations associated with lipid A act to 
bridge adjacent LPS molecules with each other [21,76]. Lipid A, the hydrophobic domain of LPS, lies on the outer membrane at the side of the phospholipid bilayer. Meanwhile, a non-repeating core oligosaccharide and a distal polysaccharide (also known as O-antigen or somatic-antigen) line the external portion of LPS, which extends to outside of the cell. Oligosaccharides are involved in growth, as well as in bacterial resistance to antibiotics, complement system, and various environmental stresses [77]. The resistance to stress is dependent on the negatively charged LPS, making the outer membrane impermeable to hydrophobic compounds, and on the outer membrane proteins folded with transmembrane domains. Some of these proteins form porins for the diffusion of small hydrophilic molecules. The outer membrane lipoproteins float among other components, giving the outer membrane an overall sophisticated composition, that is efficient to protect against toxic substances and stressful environmental conditions [78].

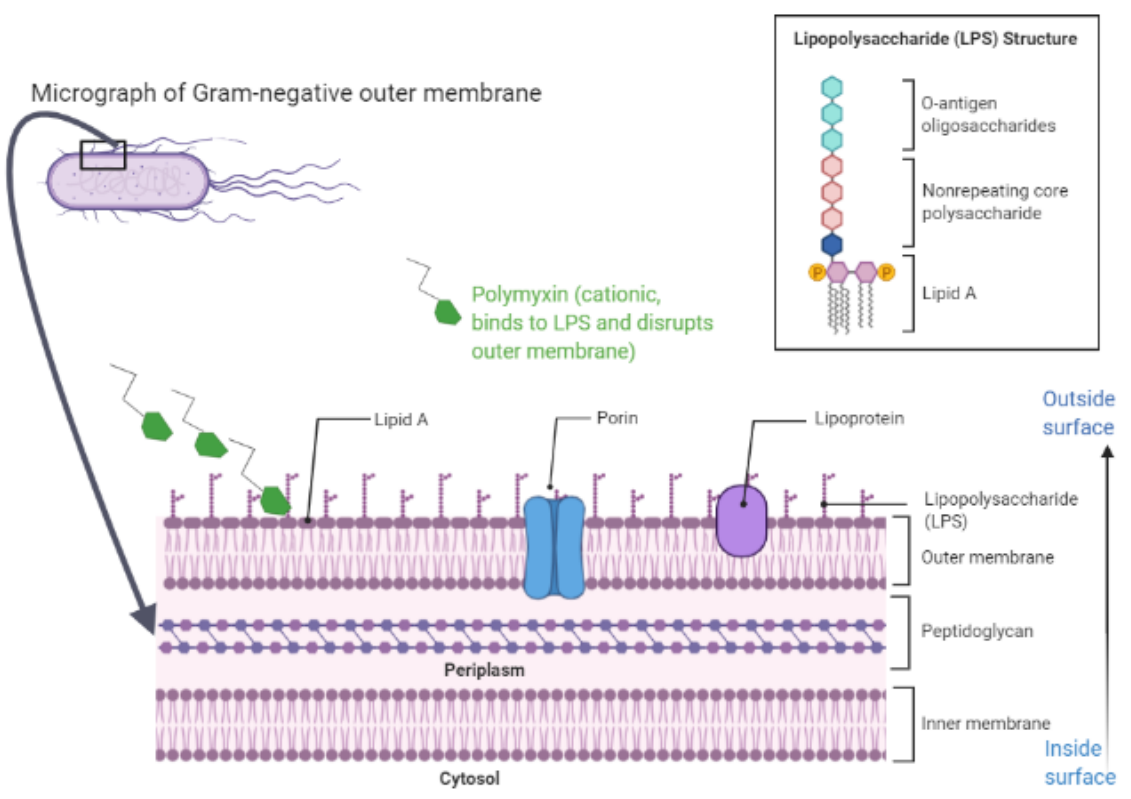

Figure 2. A schematic representation of a Gram-negative cell wall with outer membrane composition. The inner leaflet consists of phospholipids, whereas the outer leaflet shows lipopolysaccharides, lipoproteins and porins. Lipopolysaccharide components are also shown. Cationic polymyxins bind to the negatively charged components of lipopolysaccharides.

\subsection{Insights into Models of Polymyxins' Mechanism of Action}

In fact, the exact mode of action of polymyxins lingers to be argumentative. Despite an overall assumption for the membrane as the primary drug target for polymyxins, there is evidence for alternative or complementary pathways, and literature has described several models.

In one model based on outer membrane damage, consensus opinion focuses on a number of steps: (1) the initial uptake of polymyxin into the bacterial outer membrane is "self-promoted" [21]. In this process, polymyxins, with cationic affinity to LPS at least three-fold higher than that of the native divalent cations, calcium and magnesium, competitively displace these ions and, being bulky, disrupt the normal barrier property of the outer membrane. The affected outer membrane is thought to develop temporary "cracks", that permit the passage of various molecules, among which is the uptake of the polymyxin itself [79]. (2) Following this uptake, an electrostatic interaction occurs between the Dab residue of the positively charged polymyxin on one side, and the phosphate groups of the negatively charged lipid A, making lipid A the principle polymyxin-binding target in the outer membrane of Gram-negative bacteria [13]. (3) Divalent calcium and magnesium cations are displaced from the negatively charged phosphate groups of membrane lipids [12], and this displacement allows the hydrophobic fatty acyl tail of the polymyxin molecule to be inserted into the outer membrane [79]. 
(4) Such insertion weakens the packing of adjacent lipid A fatty acyl chains, causing outer membrane expansion [13]. (5) Eventually, such expansion facilitates the formation of destabilized areas through which polymyxin crosses the outer membrane. Finally, polymyxins will destroy the physical integrity of the phospholipid bilayer of the cytoplasmic (inner) membrane, and intracellular contents begin to leak out, resulting in cell death $[3,26]$.

Apart from such steps, and in other models, polymyxin is thought to mediate the fusion of the inner leaflets of the outer membrane and the outer leaflet of the inner membrane surrounding the periplasmic space [80]. Such action is believed to induce phospholipid exchange, between the leaflets of the inner and outer membranes, triggering a loss of specificity of phospholipid composition. This can potentially cause an osmotic imbalance that culminates in cell death [22]. Such a pathway, in which polymyxins bind to both anionic phospholipid vesicles, namely, inner phospholipid leaflets of outer membrane and inner membrane, promote phospholipid exchange between vesicles, is called the vesicle-vesicle contact pathway. The mechanism for the intermembrane transfer of phospholipids could be responsible for the intracellular trafficking and sorting of phospholipids; it could be a necessary step for polymyxin antibiotic action [81]. Moreover, hydrophobic interactions are assumed to occur between the N-terminal fatty acyl tail of the polymyxin molecule and the fatty acyl chains of lipid A [82]. The result of a dynamic simulation study on a laboratory strain of E. coli predicted that polymyxin B1 is likely to interact with both the inner and outer membranes via distinct mechanisms. While polymyxin B1 molecules aggregate in the LPS region of the outer membrane with restricted insertion within the lipid A tails, they readily insert into the inner membrane core. The concomitant increased hydration may be responsible for bilayer destabilization and antimicrobial function [83].

A third model of polymyxins' activity involves free radical-induced death. In bacterial cells, the activity of redox enzymes extracts the electrons from molecular oxygen, continuously forming intracellular superoxide, hydroxyl radical, and hydrogen peroxide. These species adversely affect the activities of enzymes and the integrity of DNA, lipids, and proteins, thereby compelling organisms to protect themselves with a response involving repair systems and enzymes. However, elevated levels of oxidants will eventually poison bacteria [84]. Superoxide levels are postulated to rise when polymyxin molecules enter across the Gram-negative cell wall; superoxide will be enzymatically converted to hydrogen peroxide by cellular superoxide dismutases. Then, hydrogen peroxide will oxidize ferrous iron to ferric iron, forming a hydroxyl free radical. When the concentration of the latter reaches significant levels, it will stimulate oxidative damage of biological molecules with deleterious effects on the cell, which are independent of polymyxin binding to its specific target in the outer membrane [85]. Therefore, it is suggested that some antibiotics, including polymyxin B and colistin, but also others like kanamycin, kill bacteria through oxidative stress and reactive oxygen species (ROS) generation [3]. The applicability of such a mechanism to polymyxin has been investigated in several studies. For instance, sublethal concentrations of polymyxin B induced an oxidative burst and high endogenous ROS production in P. aeruginosa [86]. Moreover, a hydroxyl radical scavenging compound, thiourea, was assessed regarding its ability to prevent the polymyxin-induced killing of A. baumannii. A striking decrease in the ability of both polymyxin B and colistin to kill A. baumannii was noticeable in the presence of thiourea, which acted as a "rescue" compound [87]. In 2015, Dong et al. showed that polymyxin stimulates the generation of ROS, but cell killing could occur by nonoxidative mechanism, typically envelope disruption. Furthermore, polymyxin stimulates the expression of a gene called soxS (for superoxide response) in E. coli, whose expression may be a strategy to prepare for the potentially lethal interactions with diffusible toxic molecules, including polymyxin. The gene soxS encodes a transcriptional activator of genes that respond to reactive oxidative (redox) stress, such as $\operatorname{sodA}$ (Mn-containing superoxide dismutase), fpr (NADPH:ferredoxin oxidoreductase), and $y d b K$ (a putative Fe-S-containing reductase) [88]. Interestingly, in 2017, it was shown that colistin induced ROS accumulation and oxidative stress-induced damage in P. polymyxa, the producer of colistin. This highlighted an unfamiliar activity of colistin against Gram-positive bacteria [89]. Moreover, the membrane damage and extensive cell surface alteration in Gram-positive bacteria was revealed 
by detecting the leakage of intracellular molecules, shedding light on a not yet described bactericidal mechanism of polymyxin E against Gram-positive bacteria [90].

Additional systems of polymyxin activity have been proposed. By binding to the LPS molecule released upon the cell lysis of Gram-negative pathogens, polymyxins cause the neutralization of the endotoxin, corresponding to lipid A of LPS, diminishing its pathophysiologic effects in the circulation [12]. Moreover, Deris et al. showed that polymyxins inhibited key respiratory enzymes, such as type II NADH-quinone oxidoreductases, which exist in the bacterial inner membrane of three Gram-negative species: E. coli, K. pneumoniae and A. baumannii, suggesting this pathway as a secondary polymyxin mode of action [91]. A recent study showed the enhancement of NADH metabolism and the resulting generation of oxidative damages in Gram-positive cells of Bacillus subtilis and P. polymyxa, giving insights into a yet unrevealed action of polymyxin in Gram-positive cells [92]. Additionally, a significant decrease in dividing cells was observed when P. aeruginosa were treated with colistin, although without significant killing [93]. In this report, an increase in cellular rigidity was noticeable, speculating that the binding of colistin to the outer membrane may stiffen the bacterial cell wall, altering its nanomechanical properties and morphology, and perturbing normal cell division. McCoy and colleagues [94] showed that polymyxins can bind to the 16S (prokaryotic) and 18S (eukaryotic) A-site RNA constructs of ribosomes, where they interfere with eukaryotic translation in vitro, but not with bacterial translation. Therefore, a possible mechanism for polymyxins by interference with bacterial ribosomes was investigated, but appears unlikely. Recently, and using a metabolomic approach, elevated glucose levels, and various glyoxylate and glycerolipid metabolic intermediates, were observed in Mycobacterium tuberculosis cultured in the presence of colistin. The increase in fatty acid synthesis and cell wall repair postulated that colistin acts by disrupting the cell wall in M. tuberculosis, in a manner similar to other bacteria [95]. In Mycobacterium smegmatis, polymyxin B inhibited the activity of the alternative NADH dehydrogenase and the malate: quinone oxidoreductase, which are both respiratory enzymes [96]. The last two models perhaps justify interest in the applicability of polymyxin as a potentiator of anti-mycobacterial drugs [97].

Overall, despite the traditional record of polymyxins as affecting bacterial membranes leading to lysis and death, there is substantial work investigating secondary mechanisms. Polymyxins shuffle phospholipids, mediate hydroxyl radical death pathways, counterbalance endotoxins, and affect normal cell reproduction and respiration. It is hoped that a deeper understanding of the mechanisms of action of these compounds will offer better insights into their pharmacological potential and clinical utility.

\section{Bacterial Resistance to Polymyxins and Changes in Membranes}

The use of polymyxins, among the few remaining valid options for the therapy of infections caused by MDR Enterobacteriaceae, P. aeruginosa and A. baumannii, has prompted the emergence of resistance to this antibiotic class, creating a major public health concern [98]. Bacterial resistance to polymyxins may be chromosomal and associated with the modification of LPS, or may be encoded on transposable genetic elements, namely $m c r$ genes [43]. A representation of the current knowledge regarding bacterial resistance to polymyxins is discussed below.

\subsection{Chromosomal Resistance}

Similar to bacterial species that are naturally resistant to polymyxins (described above), the change in the LPS total charge is responsible for developing polymyxin resistance [12]. Chromosomal mutations that lead to the addition of cationic groups to lipid A weaken the binding of polymyxins to their main target [23]. Although the exact chromosomal mechanism for lipid A modification appears to be species-specific, regulatory genes or operons such as PmrAB and PhoPQ trigger the chromosomal mechanism and are shared by many species $[99,100]$. The role of these regulatory systems is to permit bacterial cells to react to environmental changes by modifying their gene expression. When these regulatory systems interact with one another, they even have more profound effects on polymyxin resistance [101]. The net effect of the activity of these systems is the addition of cationic groups, 
4-amino-4-deoxy-L-arabinose (L-Ara4N) and pEtN, to LPS, mediating the acquired resistance to colistin [12]. Below is a panel of operons involved in this process:

1. The PhoPQ two-component system and its regulatory gene $m g r B$. This system codes for two proteins, the regulator protein PhoP and the protein kinase $P h o Q$. While the kinase senses a specific environmental stimulus, the corresponding response regulator mediates the cellular response, mostly through the differential expression of target genes. In the presence of certain environmental stimuli, this system allows the expression of virulence factors, enzymes that modify the LPS to allow resistance to cationic antimicrobial peptides, or enzymes that decrease stress due to acidic $\mathrm{pH}$. The PhoPQ two-component system promotes bacterial survival in low magnesium concentration or in acidic $\mathrm{pH}$ or in the presence of cationic antimicrobial peptides. $P h o Q$ is a protein with tyrosine kinase activity that activates PhoP through phosphorylation [102]. Active PhoP drives the transcription of the pmrHFIJKLM operon, involved in the chemical modification of LPS via the addition of L-Ara4N to the LPS. Moreover, PhoP can also activate the pmrA gene, triggering the expression of PmrA protein, causing the addition of $\mathrm{pEtN}$ to the LPS [103]. The regulation of the PhoPQ system occurs through the gene $m g r B$, which acts as a negative regulator. Upon the activation of PhoP, the $m g r B$ gene is upregulated. The translated $m g r B$ protein in turn represses the $P h o Q$ gene. The inactivation of the $m g r B$ gene leads to the overexpression of the phoPQ operon, thus causing pmrHFIJKLM operon activation, leading to the production of L-Ara4N responsible for the acquisition of polymyxin resistance. Studies show that substitutions, insertions, or deletions in the $m g r B$ gene mediate polymyxin resistance [12]. For example, in KPC-producing K. pneumoniae, the transcriptional upregulation of the $P h o Q$ gene was observed in the strains with $m g r B$ alterations, mediating colistin resistance [104]. Although $m g r B$ mutations or inactivation were suggested as major mechanisms for colistin resistance in K. pneumoniae [105-107], Borsa et al. reported an overexpression of $P h o Q$ and phoP genes in K. pneumoniae with wild-type $m g r B$ gene, suggesting that other genetic regulations of the PhoPQ system may exist [108]. A very recent report from Korea described the $m g r B$ alteration mediating colistin resistance in E. coli isolated from livestock [109]. It is noteworthy that the mutation of genes other than $m g r B$ may contribute to enhancing PhoPQ system activity, such as ColR/ColS and CprR/CprS regulatory systems in P. aeroginosa [110], and cprR/cprS in C. jejuni [99].

2. The PmrAB two-component system. Similar to the PhoPQ system, the PmrAB system is a typical two-component system, so it encodes both PmrA and PmrB. PmrB is a protein with tyrosine kinase activity, that activates the transcriptional regulator PmrA by phosphorylation. Environmental stimuli, such as macrophage phagosomes, ferric iron, aluminum ion, and low $\mathrm{pH}$, activate PmrB. PmrA in turn activates the transcription of the $\operatorname{pmrCAB}$ operon and the pmrHFIJKLM operon, that are involved in LPS modification by the addition of $\mathrm{pEtN}$ and L-Ara4N [111]. Mutations causing constitutive activation in the $p m r A$ and $p m r B$ genes have been described as being responsible for acquired colistin resistance [99]. Reports of such alterations are availble for E. coli [112], Enterobacter cloacae [113], P. aeruginosa [114], and A. baumannii [115,116].

3. The $l p x A, \operatorname{lp} x C$ and $l p x D$ genes. This unique set of genes exists in $A$. baumannii, which can become highly resistant to polymyxins via spontaneous mutations in these lipid A biosynthesis genes. If the biosynthetic lipidA genes, $\ln x A, \operatorname{lp} x C$, or $\operatorname{lp} x D$, become inactive, LPS is not formed, and interaction with polymyxins is lost [116]. In its attempt to adapt to the antibiotic pressure induced by polymyxins, A. baumannii, through the inactivation of the aforementioned genes, loses LPS, a major virulence factor and structural component. Such adaptation results in a dramatic decrease in the fitness and virulence and major changes in the physiology, thus providing insights into the low prevalence of polymyxin-resistant $A$. baumannii isolates with LPS loss in the clinical setting [117].

In addition to the cationic modifications of lipid A, some studies indicated the prevalence of other changes, such as outer membrane remodelling events, which may contribute to resistance. 
The comparative profiling of the outer membrane proteome of a laboratory strain of extremely colistin-resistant K. pneumoniae revealed that outer membrane proteins from bacterial stress response, glutamine degradation, aspartate, pyruvate, and asparagine metabolic pathways were over-represented, compared to sensitive strains [118]. In clinical strains of K. pneumoniae and Enterobacter asburiae, matrix-assisted laser desorption ionization time of flight/mass spectrometry (MALDI-TOF/MS) investigation done by a Hungarian research group identified the differences between outer membrane proteins among colistin-susceptible and -resistant counterparts. While the colistin-susceptible K. pneumoniae had $16 \mathrm{kDa}$ proteins belonging to the LysM domain/BON superfamily, as well as DNA starvation proteins, the colistin-resistant strains had OmpX and OmpW. Furthermore, OmpC and OmpW were detected in the colistin-susceptible E. asburiae, whereas OmpA and OmpX were identified in the colistin-resistant counterpart. This demonstrated that the altered Gram-negative cell wall may contribute to acquired colistin resistance in Enterobacteriaceae [119]. Another study investigated the influence of lipid A acylation pattern on the crucial interaction between the LPS of a clinical K. pneumoniae isolate and polymyxins. The underacylation of lipid A resulted in increased polymyxin susceptibility, with the hexa-acylated lipid A showing better interaction with polymyxins than the penta-acylated lipid A, perhaps unraveling a novel appreciation of the mechanisms of polymyxin activity and resistance [120].

\subsection{Plasmid-Mediated Resistance}

Until 2015, the identified mechanisms of polymyxin resistance were attributed to chromosomal mutations, and not to horizontal gene transfer. However, it was found that polymyxin resistance could also be dependent on plasmid-mediated and therefore the transferable genes, of the mobilized colistin resistance ( $m c r$ )-type [121]. Such mobile resistance is ultimately rendering the "last resort" polymyxin antibiotics therapeutically unusable, and is disseminating over wide geographic locations, as well as among animals, water, food chain and the environment [122].

The first $m c r$ gene, $m c r-1$, was identified in the E. coli of animal, human, and environmental origin recovered in China in 2015, during the routine surveillance of antimicrobial resistance in E. coli from food animals [123]. Being carried on a conjugative plasmid, $m c r-1$ exhibited an easily driven dissemination into various bacteria from animals and humans. In light of a such transferability of polymyxin resistance by $m c r-1$, it was not surprising that it rapidly swept across nearly the entire globe in less than a year since its first discovery [124]. Eventually, different variants up to $m c r-9$ were identified in various Gram-negative bacteria [43], and were reported beyond China in all continents [12]. In 2020, a novel $m c r$ gene, $m c r-10$, was identified on a plasmid of an Enterobacter roggenkampii clinical strain [125]. A summarized description of the known $m c r$ genes to date is shown in Table 2. The mor-1 gene is responsible for polymyxin resistance through encoding a $\mathrm{pEtN}$ transferase. This enzyme, similar to chromosomal resistance pathways, especially those associated with two-component systems, mediates the addition of pEtN to lipid A, making this compound highly cationic [126]. In terms of membrane changes, the $\mathrm{mcr}$ phenotype in Gram-negative bacteria is known to decrease the membrane charge and increase its packing by the chemical modification of the outer membrane. In this sense, the cationic additions reduce the negative charge and limit antimicrobial peptide binding and membrane disruption. These modifications make the outer membrane more resistant to antimicrobial peptides, and suggest that LPS modification prevents the penetration of large molecules through a strengthening of lateral interactions between neighboring LPS molecules. When lipid packing increases, the area-per-lipid in the outer membrane is reduced, and polymyxin penetration drastically decreases, as the drug preferably lies flat on the membrane and does not penetrate the cell. In general, a greater packing of lipids is believed to lower the damage caused by polymyxin, corresponding to resistance [127]. 
Table 2. The 10 discovered variants of the mobilized colistin resistance $(\mathrm{mcr})$ gene, with their species and country of first detection, as well as their sequence homology to $m c r-1$.

\begin{tabular}{|c|c|c|c|c|c|}
\hline mor Gene Type & $\begin{array}{c}\text { Species of } \\
\text { First Detection }\end{array}$ & $\begin{array}{c}\text { Country of } \\
\text { First Detection }\end{array}$ & $\begin{array}{c}\text { Sequence Homology } \\
\text { to } m c r-1(\%)\end{array}$ & Strain Information & Reference \\
\hline$m c r-1$ & Escherichia coli & China & 100 & SHP45 & [123] \\
\hline$m c r-2$ & E. coli & Belgium & 76.7 & СР011374 & [128] \\
\hline$m c r-3$ & E. coli & China & 45 & WJ1 & [129] \\
\hline$m c r-4$ & $\begin{array}{c}\text { Salmonella enterica } \\
\text { serovar Typhimurium }\end{array}$ & Italy & 34 & R3445 & [130] \\
\hline$m c r-5$ & $\begin{array}{c}\text { S. enterica subsp. } \\
\text { enterica }\end{array}$ & Germany & 63.89 & $11-00422$ & [131] \\
\hline$m c r-6$ & $\begin{array}{c}\text { Moraxella } \\
\text { pluranimalium }\end{array}$ & Great Britain & 62 & 248-01T/DSM-22804) & [132] \\
\hline$m c r-7$ & Klebsiella pneumoniae & China & 65 & SC20141012 & [133] \\
\hline$m c r-8$ & K. pneumoniae & China & 31.08 & KP91 & [134] \\
\hline$m c r-9$ & $\begin{array}{c}\text { S. enterica subsp. } \\
\text { enterica }\end{array}$ & New York & 63 & GCF_002091095.1 & [135] \\
\hline$m c r-10$ & $\begin{array}{l}\text { Enterobacter } \\
\text { roggenkampii }\end{array}$ & China & 29.31 & $\begin{array}{c}090065 \\
\text { (WCHER090065) }\end{array}$ & [125] \\
\hline
\end{tabular}

Molecular investigations of the genetic background of $\mathrm{mcr}$ genes have confirmed them on three major types of plasmids: IncI2, IncHI2 and IncX4, in addition to IncHI1, IncF, IncFI, IncFIB, IncFII, IncP, IncP-1, IncK2 and phage-like IncY [7]. Some but not all plasmids carrying the $m c r-1$ gene harbor other antimicrobial resistance genes to other antibiotics including $\beta$-lactams, aminoglycosides, quinolones, fosfomycin, sulfonamides, and tetracyclines. Hence, the location of this gene on multidrug resistance plasmids is worrisome because using other antimicrobials can selectively promote the growth of isolates carrying $m c r-1$ and their subsequent spread [12]. More importantly, the $m c r-1$ gene has been identified in highly drug-resistant pathogens harboring plasmids encoding carbapenemase genes, such as $b l a_{\mathrm{NDM}-1}, b l a_{\mathrm{NDM}-5}, b l a_{\mathrm{OXA}-48}, b l a_{\mathrm{KPC}-2}$, and $b l a_{\mathrm{VIM}-1}$, significantly complicating the therapy of infections caused by such bacteria [136,137].

The origin and associated sequences of the plasmid-encoded $\mathrm{mcr}$ remain the subject of intensive investigation, and remarkable progress in knowledge pertaining to these details is notable. In addition to the plasmid types and up to 10 variants of the gene reported so far, the insertion sequence of ISApl1 was identified to flank one or both ends of $m c r-1$, suggesting that this gene was mobilized by an ISApl1 composite transposon which has, in some cases, subsequently lost one or both copies of ISApl1 [138,139]. The transposon Tn6330 was found to be the key element mediating the translocation of mcr-1 into various plasmid backbones through the formation of a circular intermediate, and it allows the co-transmission of $m c r-1$ with other resistance determinants through IncHI2 plasmids [140]. The genetic structure harboring the gene is known as " $m c r-1$ cassette", that has a length of $2600 \mathrm{bp}$, and was found to carry its own promoter sequences driving the expression of $m c r-1$ [12]. Recently, a comprehensive analysis of all mcr-1 sequences in GenBank was used to identify a chromosomal region of a novel Moraxella species, with significant homology to the mor-1 structure, and which likely represents the origin of this gene. All mcr-1 structures lacking one or both flanking ISApl1 were obtained from ancestral composite transposons that subsequently lost the insertion sequences by a process of abortive transposition. The mobilization of $m c r-1$ occurs as part of a composite transposon and structures lacking the downstream ISApl1 are not capable of gene mobilization [141]. The combination of the ISApl1 and the mcr-1 cassette has been described on the chromosome of an E. coli isolate recovered in 2015 from raw chicken meat in Switzerland, suggesting the possible hypothesis that $\mathrm{mcr}$ genes are capable of integration and therefore stabilization in some bacterial chromosomes [142].

Epidemiologic data regarding $\mathrm{mcr}$ genes are also becoming more accessible. In a recent meta-analysis involving over 200 studies from 47 different countries across six continents [65], the overall prevalence of $\mathrm{mcr}$ genes ranged between $0.1 \%$ and $9.3 \%$, with the highest number of mcr-positive strains reported in China. Approximately 95\% of $\mathrm{mcr}$ genes were of the type $m c r-1$. The highest prevalence was in the environment (22\%), followed by animals $(11 \%)$, food $(5.4 \%)$, and humans (2.5\%). Pathogenic E. coli (54\%), isolated from animals (52\%) and harboring an IncI2 
plasmid (34\%) were the species with highest prevalence of $m c r$ genes. The significant role of food chain and/or the environment in $\mathrm{mcr}$ gene spreading is, therefore, evident and warrants further investigation. Given such a global burden of $m c r$ gene carriage, its reservoirs, and its dissemination has triggered extensive worldwide alarms [143]. Large-scale investigations are urgently required for a better understanding of the molecular epidemiology and resistance mechanisms of these genes. The proper understanding of transferable polymyxin resistance shall provide evidence to improve clinical therapeutics targeting severe infections by mor-harboring pathogens [144].

\section{Special Features and Spread of Polymyxin Resistance among Prominent Gram-Negative Pathogens}

The features of polymyxin resistance exhibit some specific distinctions among important Gram-negative pathogens, namely those of the family Enterobacteriaceae, P. aeruginosa and A. baumannii. These special features are differentiated below and summarized in Table 3.

\subsection{Enterobacteriaceae}

Among the family Enterobacteriaceae, polymyxin resistance has been described for many species, including Escherichia, Klebsiella, Salmonella, Shigella, Enterobacter, and Citrobacter [145,146], (Table 3). Several molecular mechanisms have been identified, primarily the modification of LPS through the addition of the cationic groups L-Ara4N and $\mathrm{pEtN}$ [99]. Specifically, fine gene alterations are responsible for the LPS modifications seen in members of the Enterobacteriaceae family, and they can be variable among the different species.

Table 3. Examples of chromosomal and plasmid-encoded polymyxin resistance mechanisms described in Enterobacteriaceae, Pseudomonas, and Acinetobacter.

\begin{tabular}{|c|c|c|c|c|c|}
\hline & & \multicolumn{2}{|r|}{ Chromosomal Resistance } & \multicolumn{2}{|c|}{ Plasmid-Encoded Resistance } \\
\hline & & $\begin{array}{l}\text { Two-component } \\
\text { systems [ref] }\end{array}$ & Additional mechanisms [ref] & mor type & Ref \\
\hline \multirow{6}{*}{ Enterobacteriaceae } & \multirow{2}{*}{$\begin{array}{l}\text { Klebsiella } \\
\text { pneumoniae }\end{array}$} & \multirow{2}{*}{$\begin{array}{l}\text { PhoPQ [103] } \\
\text { PmrAB [147] }\end{array}$} & \multirow{2}{*}{$\begin{array}{l}\text { Shedding of capsular polysaccharide capable of } \\
\text { trapping polymyxins [148] } \\
\text { Overexpression of the efflux pump kpnEF [149] }\end{array}$} & $m c r-2$ & {$[108,150]$} \\
\hline & & & & $m c r-7$ & [133] \\
\hline & \multirow{4}{*}{ E. coli } & \multirow{4}{*}{$\begin{array}{l}\text { PhoPQ [151] } \\
\text { PmrAB [112] }\end{array}$} & \multirow{4}{*}{$\begin{array}{c}\text { Modification of Kdo } \\
\text { (3-deoxy-D-manno-octulosonic acid) [152] }\end{array}$} & $m c r-2$ & [153] \\
\hline & & & & $m c r-3$ & [129] \\
\hline & & & & $m c r-4$ & [154] \\
\hline & & & & $m c r-5$ & [154] \\
\hline \multirow[t]{2}{*}{ Acinetobacter } & & PmrAB [167] & Expression of the efflux pump EmrAB [168] & $m c r-1$ & [166] \\
\hline & & & & $m c r-4.3$ & [169] \\
\hline
\end{tabular}

As far as K. pneumoniae is concerned, it is known that a profound molecular mechanism that leads to the emergence of polymyxin resistance in this organism is the mutation/inactivation of the $m g r B$ gene, as described above in Section 5.1 [104]. The gene $m g r B$ is a conserved gene of 141 nucleotides in length, encoding a short, 47-amino acid protein that causes negative feedback on the PhoPQ regulatory system. Another proposed mechanism that may occur on K. pneumoniae is the shedding of capsular polysaccharides from its capsulated surface $[148,170]$. These capsular compounds have the capability of binding to or trapping polymyxins, thereby depleting drug concentrations reaching the 
bacterial membranes, and increasing resistance. The proposed binding is a function of the electrostatic interactions between the cationic polymyxins and anionic capsular polysaccharides [171]. Additionally, in a report from India, it was found that a mutant form of the efflux pump KpnEF may increase sensitivity to colistin in K. pneumoniae. This pump belongs to the small multidrug resistance (SMR) protein family and is composed of four transmembrane alpha-helices that span the outer membrane and the cytoplasmic membrane. This finding raises the probability that the efflux pump overexpression may contribute to colistin resistance in this organism (Table 3) [149].

In E. coli, and parallel to the $m g r B$ mechanism, $m g r R$ is a key genetic determinant of polymyxin resistance in this organism [63]. The $m g r R$ mediates the modification of the outer Kdo (3-deoxy-D-manno-octulosonic acid) residues of LPS by adding pEtN [152]. In Salmonella, the gene mig-14 has been recently shown to contribute to polymyxin resistance through the decreasing permeability of the organism's outer membrane and endorsing biofilm formation. The reduction in permeability is thought to occur through the ability of mig-14 to suppress or inhibit the expression of outer membrane proteins OmpF and/or OmpC [157].

Apart from the above chromosomal gene alterations, Enterobacteriaceae were the first reservoir of the transferrable polymyxin resistance, with the plasmid-encoded gene $m c r-1$ being first reported in November 2015 from E. coli [123]. Horizontal spread accounted for the easy dissemination of mor genes among other members of the family. To date, E. coli remains the most prevalent species among the mcr-positive isolates, accounting over $90 \%$ of the total mcr-carrying isolates, followed by Salmonella enterica (7\%) then K. pneumoniae (2\%). As of 2019, mor has been detected in Enterobacteriaceae in 47 different countries [7]. Animals are believed to be the main reservoir of $\mathrm{mcr}$, and this is attributed in part to the heavy use of polymyxins in veterinary medicine for prophylactic purposes, and in part due to genetic background. These genes are often associated with $b l a_{\mathrm{CMY}-2}$ and flor $R$ genes, which are found in animal enterobacterial isolates, and also with an insertion sequence, ISApl1, known in Pasteurella multocida, an animal pathogen [172]. Nowadays, Enterobacteriaceae harboring $\mathrm{mcr}$ genes are recovered from patients and healthy subjects [173], hospital surfaces [174], raw meat [123], livestock [175], fresh vegetables [176], wild birds [177], and surface samples from public transportation [178], indicating community spread. Moreover, $m c r$ genes are being detected in enterobacterial isolates with other resistance genes. In Tunisia, E. coli isolates with both CTX-M-15 and mcr-1 were recovered from bovine fecal samples and raw goat milk [179]. In Brazil, the emergence of a K. pneumoniae isolate with both bla $a_{\mathrm{KPC}}$ and mor-1 was reported [180]; likewise, the same gene combination was found in Enterobacteriaceae growing in streams and wastewater treatment plants in Italy [181]. It is noteworthy to mention that $m c r-1$ was detected in Switzerland on the chromosome of an E. coli isolate recovered from chicken [142], suggesting that it may be integrated and stabilized in an enterobacterial genome.

Worldwide, the rates of polymyxin resistance in Enterobacteriaceae are widely variable. In K. pneumoniae, it reaches about $9 \%$ worldwide, while in some European countries such as Italy, Greece, Spain, and Hungary, it may rise up to $43 \%, 20.8 \%$ in Greece and over 30\% in Spain [4]. In Dubai, the resistance of Enterobacteriaceae isolates to colistin was $27 \%$ [182]. Considering the further limitations of the antimicrobial options available for the management of infections caused by MDR Enterobacteriaceae, there is no doubt that the recent reports of polymyxin resistance in these pathogens raises major concerns, and stresses the need for better surveillance and infection control.

\subsection{Pseudomonas aeruginosa}

P. aeruginosa is a Gram-negative opportunistic pathogen of hospitalized and immunocompromised patients, causing severe infections and representing a challenge to infection control. Polymyxins represent the last antibiotic option for P. aeruginosa infections [183]. Five two-component systems that regulate LPS modifications are known to mediate polymyxin resistance in P. aeruginosa (Table 3) [12]. Much alike has been seen in Enterobacteriaceae, where alterations in the PmrAB [160,184,185] and PhoPQ [159] systems have been shown to intervene in acquired resistance to colistin. One report indicated that there is a differential role for these systems, where resistance was caused by both the 
inactivation and/or amino acid substitutions in $P h o Q$, while resistance was caused only by amino acid substitutions of PmrB. Meanwhile, the alteration of both $P h o Q$ and PmrB resulted in higher levels of resistance than the alteration of either component alone [186].

The remaining three types of two-component systems shown to participate in colistin resistance in P. aeruginosa, are the CprRS [161], and ColRS [110] ParRS [162] systems. Mutations in the ColRS and CprRS two-component regulatory systems may play a major role, since the association of mutations in the PhoQ gene and mutations in the colS or cprS genes confers a high level of polymyxin resistance [110]. The action of the ColRS and CprRS systems may occur through the activation of PhoQ gene and/or through other genes that are yet to be identified [12]. Furthermore, the ParRS (polymyxin adaptive resistance) two-component system is involved in adaptative resistance to polymyxins. Mutations in this system cause the constitutive expression of pmrHFIJKLM operon with a resulting addition of L-Ara4N to the LPS [187].

In addition to the above mechanisms, and very recently, Puja and colleagues showed that the efflux pump MexXY/OprM was important in the adaptation of P. aeruginosa to polymyxins, unlocking a new perspective for restoring its susceptibility by the suggested use of efflux inhibitors [163]. In an experimental simulation of infections, where P. aeruginosa cells were cultured in the presence of cell wash fluids containing LPS, cell-free LPS derived from bacterial cells inhibited the antimicrobial activity of colistin. This indicated that large amounts of broken and dead cells of P. aeruginosa at infection sites may reduce colistin effectiveness, even in cells that have not yet acquired resistance [188]. Moreover, an investigation using lipidomics and transcriptomics discovered that polymyxin B induces lipid A deacylation in P. aeruginosa. This mechanism is considered an "innate immunity" response to polymyxins and a compensatory mechanism to L-Ara4N modification, and thus high-level polymyxin resistance in P. aeruginosa. The less hydrophobic lipid A with five acyl residues decreased polymyxin B penetration, compared to the normal form with six residues instead [164].

Transferable polymyxin resistance, represented by the spread of $\mathrm{mcr}$ genes, has been recently rising in P. aeruginosa, following its initial observation in Enterobacteriaceae. Perhaps the first report of $\mathrm{mor}$ in P. aeruginosa originated from Maryland, USA, in 2018, when Snesrud and Colleagues, through whole-genome sequencing, discovered a chromosomally encoded mcr-5 gene carried within a transposon in a colistin-nonsusceptible P. aeruginosa [165]. Following that report, another single isolate of $P$. aeruginosa harboring $m c r-1$ was detected during a multihospital survey on polymyxin resistance in Pakistan in 2019 [166]. The origin, transmissibility, and prevalence of mor genes in P. aeruginosa remains to be further identified.

The spread of $P$. aeruginosa resistant to polymyxins is variable worldwide. In a survey from Taiwan, the rate of resistance was close to $9 \%$ [189], which was about $6 \%$ in a German university hospital [190], 5\% in Spain [191], 4\% in Korea [192], and 2\% in Thailand [193]. In a cross-sectional, multicenter survey from Dubai, all the studied P. aeruginosa isolates were colistin sensitive [194]. On the other hand, the rate of resistance was $22 \%$ in a report from India [195], and 15\% in a nationwide Italian survey [196]. Ongoing surveillance is needed on a global scale, to observe and mitigate the spread of polymyxin resistance in this hostile pathogen.

\subsection{Acinetobacter baumannii}

Nosocomial infections with A. baumannii constitute a global problem, with high mortality rates and resistance to most antibiotics [197]. The rapid emergence of resistance in this top priority pathogen has revived clinical interest in polymyxins. However, resistance to this class of antibiotics in A. baumannii is on the rise [116]. Although the current rate of polymyxin-resistant A. baumannii represents less than $1 \%$ of clinical isolates, these still pose a significant challenge to public health authorities [198].

The main mechanism of polymyxins resistance in $A$. baumannii is chromosomally encoded, and relies on spontaneous mutations in lipid A biosynthesis genes, $\operatorname{lp} x A, \operatorname{lp} x C$, or $\operatorname{lp} x D$, where LPS is not formed, and interaction with polymyxins is lost [199]. Mutations detected in those genes were either substitutions, truncations, frameshifts, or insertional inactivation by the insertion sequence 
ISAba11 [200]. Moreover, the addition of cationic groups to the LPS can occur in A. baumannii and is mediated by mutations in PmrAB [201]. On another note, the overexpression of genes corresponding to reduced fluidity and the increased osmotic resistance of the outer membrane, known as lpsB, lptD, and vacJ, was shown to contribute to polymyxins' resistance in A. baumannii [202]. In a strain of A. baumannii with laboratory-induced polymyxin resistance, the expression of the efflux pump EmrAB was found to be high, validating the possible association between EmrAB efflux pumps and the decreased sensitivity to polymyxins in A. baumannii. Nevertheless, the clinical implications of this association remain to be tested [168]. In 2018, a study from Australia showed that an extra copy of the insertion sequence element ISAba125 within a gene encoding an H-NS family transcriptional regulator of A. baumannii, contributed to $\mathrm{pEtN}$ transferase and colistin resistance [203].

The conventional, chromosomally encoded resistance to polymyxins in A. baumannii has a limited spread. However, the plasmid-borne $\mathrm{mcr}$ gene has been recently described in A. baumannii. There have recently been reports of $m c r-4$ from the Czech Republic [204], mcr-1 from Pakistan [166], as well as mcr-4.3 from China [169] and Brazil [205]. The explication of genotypic profiles and resistance mechanisms are essential to control resistance to polymyxins in A. baumannii, thereby preserving this antibiotic class as a treatment option.

\section{Future Implications}

With the necessity of polymyxins for the management of MDR infections, it is anticipated, like what has been seen with other classes of antibiotics, novel generation polymyxins will be sought. Therefore, improving the properties of the two clinically available polymyxins shall be of prodigious interest to researchers focusing on antimicrobial development. Over the last decade, and in light of the augmented research on polymyxin pharmacology, the mode of action and toxicity, as well as the chemical and molecular elucidation of resistance, investigations have yielded a number of promising pathways to boost polymyxins efficacy and safety and reduce bacterial resistance [8].

For example, and in terms of medicinal chemistry, it was discovered that the incorporation of amino acid residues with long lipophilic alkyl or biphenyl side chains, such as octyl-glycine and biphenylalanine, at positions 6 or 7 of the polymyxin molecule, resulting in better activity against resistant isolates [206]. The observation that the $\mathrm{N}$-terminal fatty acyl chain represents a major cause for nephrotoxicity, has directed chemical modification efforts to re-construct polymyxins by focusing not only on the N-terminal fatty acyl group, but also to look beyond the peripheries of the polymyxin scaffold and examine all the amino acid residues within the polymyxin core structure. This has given rise to exciting novel compounds, which should be further refined to structurally uncouple the antimicrobial activity from nephrotoxicity [25].

Other efforts are focusing on modified polymyxin formulations or synergistic combinations that decrease toxicity; Yu and colleagues have recently developed an inhalable liposomal mixture of colistin and ciprofloxacin, that showed high effectiveness against $P$. aeruginosa [207]. Other interesting formulations of polymyxins are structured gels based on natural and synthetic polymers [208]. For example, phenylboronic acid polycarbonate hydrogels, that are loaded with polymyxin B, demonstrated in vitro antimicrobial efficacy against $P$. aeruginosa from burn wound infections [209]. The use of microneedles for the transdermal delivery of drugs into the systemic circulation was also investigated for polymyxins. A microneedle system composed of sugar, polyvinylpyrrolidone and encapsulated polymyxin B, was developed and used against Salmonella typhimurium, with the achievement of a high antibiotic level in models of porcine skin $[210,211]$. Innovative delivery systems of polymyxins include microparticles, nanoparticles, liposomes, and niosomes [208]. A niosome is a non-ionic vesicle comprising a non-ionic surfactant and cholesterol, and can incorporate both hydrophilic drugs (in its aqueous layer) and lipophilic drugs (in its vesicular lipid membrane) [212]. Niosomes can enhance the delivery of poorly absorbable drugs and increase drug absorption and bioavailability by the penetration of the GIT barrier. Polymyxin B niosomes were formulated using sorbitan monostearate surfactant and cholesterol to improve intestinal permeability. They protected polymyxin B from the GIT environment and increased its absorption within the normal 
limits of nephrotoxicity, indicating that niosomes improve the oral bioavailability of polymyxin B. There is no increase in the side effects with this mode of delivery [213]. Therefore, the improved delivery and actions of polymyxins shall be obtained by a blend of chemistry, nanotechnology, and pharmaceutics.

The recent trending strategy in testing FDA-approved medications that have no antibacterial activity in combination with antibacterials to enhance the latter's effect is being applied to polymyxins. In a truly ground-breaking approach, researchers from Australia found that a combination of polymyxin $\mathrm{B}$ and the selective serotonin reuptake inhibitor, sertraline, resulted in greater damage to P. aeruginosa, highlighting the likely possibilities of this combination for the treatment of central nervous system infections [214]. Moreover, the experimental antitumor compound PFK-158 was found to enhance the activity of colistin and delay resistance emergence in mice infected with Enterobacteriaceae [215]. In clinical trials, colistin showed synergistic activity with the antiviral drug azidothymidine in the management of urinary tract infections caused by mcr-1-producing E. coli [216]. A trial combining polymyxin $B$ with the estrogen modulator tamoxifen detected a remarkable decrease in the essential precursor metabolites of L-Ara $4 \mathrm{~N}$, interfering with a major mechanism of polymyxin resistance. The combination had a synergistic bactericidal effect on polymyxin-resistant $P$. aeruginosa in a cystic fibrosis metabolomic model [217].

Apart from such an approach, and considering the research on antimicrobial peptides other than polymyxins, in a study testing experimental cationic antimicrobial peptides, Geitani and colleagues [218] showed that the minimum inhibitory concentrations of colistin on $P$. aeruginosa were reduced by eight-fold in the presence of these peptides, probably suggesting an interesting alternative combination for resistant strains. Moreover, in a Turkish investigation on P. aeruginosa biofilms that were initially resistant to therapeutic concentrations of antibiotics, colistin was synergistic with antimicrobial peptides for inhibiting the attachment of bacterial cells to a biofilm surface as well as inhibiting biofilm formation [219]. Such examples may prove useful in future attempts to combine polymyxins with antimicrobial peptides as an interesting alternative mode of treatment of MDR pathogens.

In brief, industry and research groups across the globe are still gearing up to develop new polymyxins that are safer and more effective than the currently approved polymyxin B and colistin. For instance, avoiding direct modifications to the polymyxin scaffold while attempting to mimic the physicochemical properties of polymyxins resulted in a series of cyclic amphipathic peptides consisting of alternating cationic and nonpolar amino acid residues, loosely based on the amphipathic properties of polymyxins. These compounds displayed potent antimicrobial activity and a high affinity for LPS [220]. A study by a group from the U.K. and U.S.A. recently reported a series of promising next generation polymyxin nonapeptides with an amine-containing N-terminal moiety of specific regional conformation and stereochemistry. These compounds demonstrated superior in vitro activity and inferior cytotoxicity compared to polymyxin B. A subgroup of these compounds having a $\beta$-branched aminobutyrate N-terminus with an aryl substituent also offered low cytotoxicity, and candidates were selected for additional development [221]. The future holds potential for these drug discovery and development programs to bring upgraded polymyxins or novel polymyxin-including combinations from the bench into the clinic.

\section{Conclusions}

To date, significant progress has been made in understanding the activity of polymyxins and unraveling bacterial resistance mechanisms to this refreshed category of antibacterial compounds. However, additional investigations are still underway to obtain a better understanding of membrane interactions, bacterial resistance, and improved clinical utility. In light of increasing resistance to polymyxins, there is a critical need for restricting their use, as well as for effective infection prevention and control measures. Integrated efforts should aim at the robust enquiry of the molecular epidemiology of resistance, and the surveillance of rates and dissemination of resistance among humans, animals, and the environment. The spread of the plasmid-mediated $m c r-1$ resistance gene is a principal culprit 
to polymyxins, which, if unlimited, the real devastating loss of a life-saver antibiotic class may happen soon.

Funding: The APC was funded by Zayed University.

Conflicts of Interest: The author declares no conflict of interest.

$\begin{array}{ll}\text { Abbreviations } & \\ \text { CLSI } & \text { Clinical Laboratory and Standards Institute } \\ \text { CMS } & \text { colistimethate sodium } \\ \text { Dab } & \text { L- } \alpha, \gamma \text {-diaminobutyric acid } \\ \text { EUCAST } & \text { European Committee on Antimicrobial Susceptibility Testing } \\ \text { Kdo } & \text { 3-deoxy-D-manno-octulosonic acid } \\ \text { L-Ara4N } & \text { 4-amino-4-deoxy-L-arabinose } \\ \text { Leu } & \text { leucine } \\ \text { LPS } & \text { lipopolysaccharide } \\ \text { MALDI-TOF/MS } & \text { matrix-assisted laser desorption ionization time of flight/mass spectrometry } \\ \text { mcr } & \text { mobilized colistin resistance } \\ \text { MDR } & \text { multi-drug resistant } \\ \text { MIC } & \text { mimimum inhibitory concentration } \\ \text { pEtN } & \text { phosphoethanolamine } \\ \text { ROS } & \text { reactive oxygen species } \\ \text { SMR } & \text { small multidrug resistance } \\ \text { Thr } & \text { threonine }\end{array}$

\section{References}

1. Breijyeh, Z.; Jubeh, B.; Karaman, R. Resistance of Gram-Negative Bacteria to Current Antibacterial Agents and Approaches to Resolve it. Molecules 2020, 25, 1340. [CrossRef] [PubMed]

2. Otsuka, Y. Potent Antibiotics Active against Multidrug-Resistant Gram-Negative Bacteria. Chem. Pharm. Bull. 2020, 68, 182-190. [CrossRef] [PubMed]

3. Trimble, M.J.; Mlynárčik, P.; Kolář, M.; Hancock, R.E.W. Polymyxin: Alternative Mechanisms of Action and Resistance. Cold Spring Harb. Perspect. Med. 2016, 6. [CrossRef] [PubMed]

4. Petrosillo, N.; Taglietti, F.; Granata, G. Treatment Options for Colistin Resistant Klebsiella pneumoniae: Present and Future. J. Clin. Med. 2019, 8, 934. [CrossRef] [PubMed]

5. Tumbarello, M.; Losito, A.R.; Giamarellou, H. Optimizing therapy in carbapenem-resistant Enterobacteriaceae infections. Curr. Opin. Infect. Dis. 2018, 31, 566-577. [CrossRef]

6. El-Sayed Ahmed, M.A.E.-G.; Zhong, L.-L.; Shen, C.; Yang, Y.; Doi, Y.; Tian, G.-B. Colistin and its role in the Era of antibiotic resistance: An extended review (2000-2019). Emerg. Microbes Infect. 2020, 9, 868-885. [CrossRef]

7. Nang, S.C.; Li, J.; Velkov, T. The rise and spread of mor plasmid-mediated polymyxin resistance. Crit. Rev. Microbiol. 2019, 45, 131-161. [CrossRef]

8. Velkov, T.; Roberts, K.D.; Thompson, P.E.; Li, J. Polymyxins: A new hope in combating Gram-negative superbugs? Future Med. Chem. 2016, 8, 1017-1025. [CrossRef]

9. Benedict, R.G.; Langlykke, A.F. Antibiotic activity of Bacillus polymyxa. J. Bacteriol. 1947, 54, 24.

10. Stansly, P.G.; Shepherd, R.G.; White, H.J. Polymyxin: A new chemotherapeutic agent. Bull. Johns Hopkins Hosp. $1947,81,43-54$.

11. Stansly, P.G. The polymyxins: A review and assessment. Am. J. Med. 1949, 7, 807-818. [CrossRef]

12. Poirel, L.; Jayol, A.; Nordmann, P. Polymyxins: Antibacterial Activity, Susceptibility Testing, and Resistance Mechanisms Encoded by Plasmids or Chromosomes. Clin. Microbiol. Rev. 2017, 30, 557-596. [CrossRef] [PubMed]

13. Velkov, T.; Thompson, P.E.; Nation, R.L.; Li, J. Structure-Activity Relationships of Polymyxin Antibiotics. J. Med. Chem. 2010, 53, 1898-1916. [CrossRef] [PubMed] 
14. Zavascki, A.P.; Goldani, L.Z.; Li, J.; Nation, R.L. Polymyxin B for the treatment of multidrug-resistant pathogens: A critical review. J. Antimicrob. Chemother. 2007, 60, 1206-1215. [CrossRef]

15. Poudyal, A.; Howden, B.P.; Bell, J.M.; Gao, W.; Owen, R.J.; Turnidge, J.D.; Nation, R.L.; Li, J. In vitro pharmacodynamics of colistin against multidrug-resistant Klebsiella pneumoniae. J. Antimicrob. Chemother. 2008, 62, 1311-1318. [CrossRef]

16. Levin, A.S.; Barone, A.A.; Penço, J.; Santos, M.V.; Marinho, I.S.; Arruda, E.A.; Manrique, E.I.; Costa, S.F. Intravenous colistin as therapy for nosocomial infections caused by multidrug-resistant Pseudomonas aeruginosa and Acinetobacter baumannii. Clin. Infect. Dis. Off. Publ. Infect. Dis. Soc. Am. 1999, 28, 1008-1011. [CrossRef]

17. Markou, N.; Apostolakos, H.; Koumoudiou, C.; Athanasiou, M.; Koutsoukou, A.; Alamanos, I.; Gregorakos, L. Intravenous colistin in the treatment of sepsis from multiresistant Gram-negative bacilli in critically ill patients. Crit. Care Lond. Engl. 2003, 7, R78-R83. [CrossRef]

18. Nation, R.L.; Velkov, T.; Li, J. Colistin and polymyxin B: Peas in a pod, or chalk and cheese? Clin. Infect. Dis. Off. Publ. Infect. Dis. Soc. Am. 2014, 59, 88-94. [CrossRef]

19. Vaara, M. Polymyxins and their Potential Next Generation as Therapeutic Antibiotics. Front. Microbiol. 2019, 10, 1689. [CrossRef]

20. Yu, Z.; Qin, W.; Lin, J.; Fang, S.; Qiu, J. Antibacterial mechanisms of polymyxin and bacterial resistance. BioMed Res. Int. 2015, 2015, 679109. [CrossRef]

21. Velkov, T.; Roberts, K.D.; Nation, R.L.; Thompson, P.E.; Li, J. Pharmacology of polymyxins: New insights into an "old" class of antibiotics. Future Microbiol. 2013, 8, 711-724. [CrossRef] [PubMed]

22. Clausell, A.; Garcia-Subirats, M.; Pujol, M.; Busquets, M.A.; Rabanal, F.; Cajal, Y. Gram-negative outer and inner membrane models: Insertion of cyclic cationic lipopeptides. J. Phys. Chem. B 2007, 111, 551-563. [CrossRef] [PubMed]

23. Baron, S.; Hadjadj, L.; Rolain, J.-M.; Olaitan, A.O. Molecular mechanisms of polymyxin resistance: Knowns and unknowns. Int. J. Antimicrob. Agents 2016, 48, 583-591. [CrossRef] [PubMed]

24. Gallardo-Godoy, A.; Hansford, K.A.; Muldoon, C.; Becker, B.; Elliott, A.G.; Huang, J.X.; Pelingon, R.; Butler, M.S.; Blaskovich, M.A.T.; Cooper, M.A. Structure-Function Studies of Polymyxin B Lipononapeptides. Molecules 2019, 24, 553. [CrossRef]

25. Magee, T.V.; Brown, M.F.; Starr, J.T.; Ackley, D.C.; Abramite, J.A.; Aubrecht, J.; Butler, A.; Crandon, J.L.; Dib-Hajj, F.; Flanagan, M.E.; et al. Discovery of Dap-3 polymyxin analogues for the treatment of multidrug-resistant Gram-negative nosocomial infections. J. Med. Chem. 2013, 56, 5079-5093. [CrossRef]

26. Pristovsek, P.; Kidric, J. The search for molecular determinants of LPS inhibition by proteins and peptides. Curr. Top. Med. Chem. 2004, 4, 1185-1201. [CrossRef]

27. Tsubery, H.; Ofek, I.; Cohen, S.; Fridkin, M. Structure-function studies of polymyxin B nonapeptide: Implications to sensitization of gram-negative bacteria. J. Med. Chem. 2000, 43, 3085-3092. [CrossRef]

28. The European Committee on Antimicrobial Susceptibility Testing (EUCAST). Breakpoint Tables for Interpretation of MICs and Zone Diameters. Version 10.0. 2020. Available online: http://www.eucast.org (accessed on 3 August 2020).

29. Clinical Laboratory and Standards Instiute (CLSI). Performance Standards for Antimicrobial Susceptibility Testing, 30th ed.; M100 2020; Clinical and Laboratory Standards Institute: Wayne, PA, USA, 2020.

30. Niks, M.; Hanzen, J.; Ohlasová, D.; Rovná, D.; Purgelová, A.; Szövényiová, Z.; Vaculíková, A. Multiresistant nosocomial bacterial strains and their "in vitro" susceptibility to chloramphenicol and colistin. Klin. Mikrobiol. Infekcni Lek. 2004, 10, 124-129.

31. Falagas, M.E.; Kasiakou, S.K. Colistin: The revival of polymyxins for the management of multidrug-resistant gram-negative bacterial infections. Clin. Infect. Dis. Off. Publ. Infect. Dis. Soc. Am. 2005, 40, 1333-1341. [CrossRef]

32. Liu, M.-C.; Lin, S.-B.; Chien, H.-F.; Wang, W.-B.; Yuan, Y.-H.; Hsueh, P.-R.; Liaw, S.-J. $10^{\prime}(Z), 13^{\prime}(E)$-heptadecadienylhydroquinone inhibits swarming and virulence factors and increases polymyxin B susceptibility in Proteus mirabilis. PLoS ONE 2012, 7, e45563. [CrossRef]

33. Jiang, S.-S.; Liu, M.-C.; Teng, L.-J.; Wang, W.-B.; Hsueh, P.-R.; Liaw, S.-J. Proteus mirabilis pmrI, an RppA-regulated gene necessary for polymyxin B resistance, biofilm formation, and urothelial cell invasion. Antimicrob. Agents Chemother. 2010, 54, 1564-1571. [CrossRef] [PubMed] 
34. Kerrinnes, T.; Young, B.M.; Leon, C.; Roux, C.M.; Tran, L.; Atluri, V.L.; Winter, M.G.; Tsolis, R.M. Phospholipase A1 modulates the cell envelope phospholipid content of Brucella melitensis, contributing to polymyxin resistance and pathogenicity. Antimicrob. Agents Chemother. 2015, 59, 6717-6724. [CrossRef] [PubMed]

35. Fage, C.D.; Brown, D.B.; Boll, J.M.; Keatinge-Clay, A.T.; Trent, M.S. Crystallographic study of the phosphoethanolamine transferase EptC required for polymyxin resistance and motility in Campylobacter jejuni. Acta Crystallogr. D Biol. Crystallogr. 2014, 70, 2730-2739. [CrossRef] [PubMed]

36. Sorlózano-Puerto, A.; Carrillo-Ávila, J.A.; Gutiérrez-Soto, M.; Navarro-Marí, J.M.; Gutiérrez-Fernández, J. Susceptibility of clinical isolates of Campylobacter jejuni and Campylobacter coli to colistin. New Microbiol. 2018, 41, 235-237. [PubMed]

37. Bergen, P.J.; Landersdorfer, C.B.; Zhang, J.; Zhao, M.; Lee, H.J.; Nation, R.L.; Li, J. Pharmacokinetics and pharmacodynamics of "old" polymyxins: What is new? Diagn. Microbiol. Infect. Dis. 2012, 74, 213-223. [CrossRef]

38. Tran, T.B.; Velkov, T.; Nation, R.L.; Forrest, A.; Tsuji, B.T.; Bergen, P.J.; Li, J. Pharmacokinetics/pharmacodynamics of colistin and polymyxin B: Are we there yet? Int. J. Antimicrob. Agents 2016, 48, 592-597. [CrossRef]

39. Barnett, M.; Bushby, S.R.; Wilkinson, S. Sodium Sulphomethyl Derivatives of Polymyxins. Br. J. Pharmacol. Chemother. 1964, 23, 552-574. [CrossRef]

40. Bergen, P.J.; Li, J.; Rayner, C.R.; Nation, R.L. Colistin methanesulfonate is an inactive prodrug of colistin against Pseudomonas aeruginosa. Antimicrob. Agents Chemother. 2006, 50, 1953-1958. [CrossRef]

41. Beveridge, E.G.; Martin, A.J. Sodium sulphomethyl derivatives of polymyxins. Br. J. Pharmacol. Chemother. 1967, 29, 125-135. [CrossRef]

42. Li, J.; Nation, R.L.; Milne, R.W.; Turnidge, J.D.; Coulthard, K. Evaluation of colistin as an agent against multi-resistant Gram-negative bacteria. Int. J. Antimicrob. Agents 2005, 25, 11-25. [CrossRef]

43. Stefaniuk, E.M.; Tyski, S. Colistin Resistance in Enterobacterales Strains-A Current View. Pol. J. Microbiol. 2019, 68, 417-427. [CrossRef] [PubMed]

44. Nation, R.L.; Li, J.; Cars, O.; Couet, W.; Dudley, M.N.; Kaye, K.S.; Mouton, J.W.; Paterson, D.L.; Tam, V.H.; Theuretzbacher, U.; et al. Framework for optimisation of the clinical use of colistin and polymyxin B: The Prato polymyxin consensus. Lancet Infect. Dis. 2015, 15, 225-234. [CrossRef]

45. Tsuji, B.T.; Pogue, J.M.; Zavascki, A.P.; Paul, M.; Daikos, G.L.; Forrest, A.; Giacobbe, D.R.; Viscoli, C.; Giamarellou, H.; Karaiskos, I.; et al. International Consensus Guidelines for the Optimal Use of the Polymyxins: Endorsed by the American College of Clinical Pharmacy (ACCP), European Society of Clinical Microbiology and Infectious Diseases (ESCMID), Infectious Diseases Society of America (IDSA), International Society for Anti-Infective Pharmacology (ISAP), Society of Critical Care Medicine (SCCM), and Society of Infectious Diseases Pharmacists (SIDP). Pharmacotherapy 2019, 39, 10-39. [CrossRef]

46. Hewer, S.C.L.; Smyth, A.R. Antibiotic strategies for eradicating Pseudomonas aeruginosa in people with cystic fibrosis. Cochrane Database Syst. Rev. 2017, 4, CD004197. [CrossRef]

47. Bargiacchi, O.; De Rosa, F.G. Intrathecal or intraventricular colistin: A review. Infez. Med. 2016, 24, 3-11. [PubMed]

48. Robert, P.Y.; Adenis, J.P. Comparative review of topical ophthalmic antibacterial preparations. Drugs 2001, 61, 175-185. [CrossRef]

49. Kumar, N.; Singh, Y.; Yadav, G.; Mathur, S.K.; Bhadani, U.K. Role of neomycin polymyxin sulfate solution bladder wash for prevention of catheter associated urinary tract infection in traumatic brain injury patient admitted to Intensive Care Unit: A prospective randomized study. Int. J. Crit. Illn. Inj. Sci. 2018, 8, 17-21. [CrossRef]

50. Amani, S.; Moeini, M. Comparison of Boric Acid and Combination Drug of Polymyxin, Neomycin and Hydrocortisone (Polymyxin NH) in the Treatment of Acute Otitis Externa. J. Clin. Diagn. Res. 2016, 10, MC01-MC04. [CrossRef]

51. Marchand, S.; Lamarche, I.; Gobin, P.; Couet, W. Dose-ranging pharmacokinetics of colistin methanesulphonate (CMS) and colistin in rats following single intravenous CMS doses. J. Antimicrob. Chemother. 2010, 65, 1753-1758. [CrossRef]

52. Zavascki, A.P.; Nation, R.L. Nephrotoxicity of Polymyxins: Is there any Difference between Colistimethate and Polymyxin B? Antimicrob. Agents Chemother. 2017, 61. [CrossRef]

53. Kelesidis, T.; Falagas, M.E. The safety of polymyxin antibiotics. Expert Opin. Drug Saf. 2015, 14, 1687-1701. [CrossRef] [PubMed] 
54. Justo, J.A.; Bosso, J.A. Adverse reactions associated with systemic polymyxin therapy. Pharmacotherapy 2015, 35, 28-33. [CrossRef] [PubMed]

55. Nation, R.L.; Garonzik, S.M.; Li, J.; Thamlikitkul, V.; Giamarellos-Bourboulis, E.J.; Paterson, D.L.; Turnidge, J.D.; Forrest, A.; Silveira, F.P. Updated US and European dose Recommendations for Intravenous Colistin: How do they Perform? Clin. Infect. Dis. Off. Publ. Infect. Dis. Soc. Am. 2016, 62, 552-558. [CrossRef]

56. Manchandani, P.; Zhou, J.; Ledesma, K.R.; Truong, L.D.; Chow, D.S.-L.; Eriksen, J.L.; Tam, V.H. Characterization of Polymyxin B Biodistribution and Disposition in an Animal Model. Antimicrob. Agents Chemother. 2016, 60, 1029-1034. [CrossRef] [PubMed]

57. Dai, C.; Li, J.; Tang, S.; Li, J.; Xiao, X. Colistin-induced nephrotoxicity in mice involves the mitochondrial, death receptor, and endoplasmic reticulum pathways. Antimicrob. Agents Chemother. 2014, 58, 4075-4085. [CrossRef]

58. Falagas, M.E.; Kasiakou, S.K. Toxicity of polymyxins: A systematic review of the evidence from old and recent studies. Crit. Care Lond. Engl. 2006, 10, R27. [CrossRef]

59. Dai, C.; Xiao, X.; Li, J.; Ciccotosto, G.D.; Cappai, R.; Tang, S.; Schneider-Futschik, E.K.; Hoyer, D.; Velkov, T.; Shen, J. Molecular Mechanisms of Neurotoxicity Induced by Polymyxins and Chemoprevention. ACS Chem. Neurosci. 2019, 10, 120-131. [CrossRef]

60. Dai, C.; Tang, S.; Velkov, T.; Xiao, X. Colistin-Induced Apoptosis of Neuroblastoma-2a Cells Involves the Generation of Reactive Oxygen Species, Mitochondrial Dysfunction, and Autophagy. Mol. Neurobiol. 2016, 53, 4685-4700. [CrossRef]

61. Dai, C.; Ciccotosto, G.D.; Cappai, R.; Wang, Y.; Tang, S.; Xiao, X.; Velkov, T. Minocycline attenuates colistin-induced neurotoxicity via suppression of apoptosis, mitochondrial dysfunction and oxidative stress. J. Antimicrob. Chemother. 2017, 72, 1635-1645. [CrossRef]

62. Dai, C.; Ciccotosto, G.D.; Cappai, R.; Wang, Y.; Tang, S.; Hoyer, D.; Schneider, E.K.; Velkov, T.; Xiao, X. Rapamycin Confers Neuroprotection against Colistin-Induced Oxidative Stress, Mitochondria Dysfunction, and Apoptosis through the Activation of Autophagy and mTOR/Akt/CREB Signaling Pathways. ACS Chem. Neurosci. 2018, 9, 824-837. [CrossRef]

63. Li, Y.M.; Milikowski, C.; Selvaggi, G.; Abbo, L.M.; Skiada, D.; Galimberti, F. Polymyxin B-induced skin hyperpigmentation. Transpl. Infect. Dis. Off. J. Transplant. Soc. 2020, e13312. [CrossRef]

64. Mattos, K.P.H.; Cintra, M.L.; Gouvêa, I.R.; Ferreira, L.Á.; Velho, P.E.N.F.; Moriel, P. Skin hyperpigmentation following intravenous polymyxin $\mathrm{B}$ treatment associated with melanocyte activation and inflammatory process. J. Clin. Pharm. Ther. 2017, 42, 573-578. [CrossRef] [PubMed]

65. Elbediwi, M.; Li, Y.; Paudyal, N.; Pan, H.; Li, X.; Xie, S.; Rajkovic, A.; Feng, Y.; Fang, W.; Rankin, S.C.; et al. Global Burden of Colistin-Resistant Bacteria: Mobilized Colistin Resistance Genes Study (1980-2018). Microorganisms 2019, 7, 461. [CrossRef]

66. Evans, M.E.; Feola, D.J.; Rapp, R.P. Polymyxin B sulfate and colistin: Old antibiotics for emerging multiresistant gram-negative bacteria. Ann. Pharmacother. 1999, 33, 960-967. [CrossRef] [PubMed]

67. Silhavy, T.J.; Kahne, D.; Walker, S. The bacterial cell envelope. Cold Spring Harb. Perspect. Biol. 2010, 2 , a000414. [CrossRef]

68. Choi, U.; Lee, C.-R. Antimicrobial Agents that Inhibit the Outer Membrane Assembly Machines of Gram-Negative Bacteria. J. Microbiol. Biotechnol. 2019, 29, 1-10. [CrossRef]

69. Patel, D.S.; Qi, Y.; Im, W. Modeling and simulation of bacterial outer membranes and interactions with membrane proteins. Curr. Opin. Struct. Biol. 2017, 43, 131-140. [CrossRef]

70. May, K.L.; Silhavy, T.J. Making a membrane on the other side of the wall. Biochim. Biophys. Acta Mol. Cell Biol. Lipids 2017, 1862, 1386-1393. [CrossRef]

71. Grabowicz, M. Lipoprotein Transport: Greasing the Machines of Outer Membrane Biogenesis: Re-Examining Lipoprotein Transport Mechanisms Among Diverse Gram-Negative Bacteria While Exploring New Discoveries and Questions. BioEssays News Rev. Mol. Cell. Dev. Biol. 2018, 40, e1700187. [CrossRef]

72. Zeth, K.; Thein, M. Porins in prokaryotes and eukaryotes: Common themes and variations. Biochem. J. 2010, 431, 13-22. [CrossRef]

73. Doerrler, W.T. Lipid trafficking to the outer membrane of Gram-negative bacteria. Mol. Microbiol. 2006, 60, 542-552. [CrossRef] [PubMed]

74. Riedemann, N.C.; Guo, R.-F.; Ward, P.A. The enigma of sepsis. J. Clin. Investig. 2003, 112, 460-467. [CrossRef] [PubMed] 
75. Molinaro, A.; Holst, O.; Di Lorenzo, F.; Callaghan, M.; Nurisso, A.; D’Errico, G.; Zamyatina, A.; Peri, F.; Berisio, R.; Jerala, R.; et al. Chemistry of lipid A: At the heart of innate immunity. Chem. Weinh. Bergstr. Ger. 2015, 21, 500-519. [CrossRef]

76. Kawahara, K. Synthetic chemistry with friendships that unveiled the long-lasting mystery of lipid A. Innate Immun. 2019, 25, 203-212. [CrossRef] [PubMed]

77. Raetz, C.R.H.; Whitfield, C. Lipopolysaccharide endotoxins. Annu. Rev. Biochem. 2002, 71, 635-700. [CrossRef]

78. Laloux, G.; Collet, J.-F. Major Tom to Ground Control: How Lipoproteins Communicate Extracytoplasmic Stress to the Decision Center of the Cell. J. Bacteriol. 2017, 199. [CrossRef]

79. Re, H.; Ds, C. Peptide Antibiotics. Available online: https://pubmed.ncbi.nlm.nih.gov/10348745/?from_ single_result=peptide+antibiotics+chapple+1999 (accessed on 10 June 2020).

80. Clausell, A.; Rabanal, F.; Garcia-Subirats, M.; Alsina, M.A.; Cajal, Y. Membrane association and contact formation by a synthetic analogue of polymyxin B and its fluorescent derivatives. J. Phys. Chem. B 2006, 110, 4465-4471. [CrossRef]

81. Cajal, Y.; Rogers, J.; Berg, O.G.; Jain, M.K. Intermembrane molecular contacts by polymyxin B mediate exchange of phospholipids. Biochemistry 1996, 35, 299-308. [CrossRef]

82. Deris, Z.Z.; Swarbrick, J.D.; Roberts, K.D.; Azad, M.A.K.; Akter, J.; Horne, A.S.; Nation, R.L.; Rogers, K.L.; Thompson, P.E.; Velkov, T.; et al. Probing the penetration of antimicrobial polymyxin lipopeptides into gram-negative bacteria. Bioconjug. Chem. 2014, 25, 750-760. [CrossRef]

83. Berglund, N.A.; Piggot, T.J.; Jefferies, D.; Sessions, R.B.; Bond, P.J.; Khalid, S. Interaction of the antimicrobial peptide polymyxin B1 with both membranes of E. coli: A molecular dynamics study. PLoS Comput. Biol. 2015, 11, e1004180. [CrossRef]

84. Imlay, J.A. The molecular mechanisms and physiological consequences of oxidative stress: Lessons from a model bacterium. Nat. Rev. Microbiol. 2013, 11, 443-454. [CrossRef] [PubMed]

85. Kohanski, M.A.; Dwyer, D.J.; Hayete, B.; Lawrence, C.A.; Collins, J.J. A common mechanism of cellular death induced by bactericidal antibiotics. Cell 2007, 130, 797-810. [CrossRef] [PubMed]

86. Lima, M.R.; Ferreira, G.F.; Neto, W.R.N.; De Melo Monteiro, J.; Santos, Á.R.C.; Tavares, P.B.; Denadai, Â.M.L.; Bomfim, M.R.Q.; Dos Santos, V.L.; Marques, S.G.; et al. Evaluation of the interaction between polymyxin $\mathrm{B}$ and Pseudomonas aeruginosa biofilm and planktonic cells: Reactive oxygen species induction and zeta potential. BMC Microbiol. 2019, 19, 115. [CrossRef] [PubMed]

87. Sampson, T.R.; Liu, X.; Schroeder, M.R.; Kraft, C.S.; Burd, E.M.; Weiss, D.S. Rapid killing of Acinetobacter baumannii by polymyxins is mediated by a hydroxyl radical death pathway. Antimicrob. Agents Chemother. 2012, 56, 5642-5649. [CrossRef]

88. Dong, T.G.; Dong, S.; Catalano, C.; Moore, R.; Liang, X.; Mekalanos, J.J. Generation of reactive oxygen species by lethal attacks from competing microbes. Proc. Natl. Acad. Sci. USA 2015, 112, 2181-2186. [CrossRef]

89. Yu, Z.; Zhu, Y.; Qin, W.; Yin, J.; Qiu, J. Oxidative Stress Induced by Polymyxin E is Involved in Rapid Killing of Paenibacillus Polymyxa. BioMed Res. Int. 2017, 2017, 5437139. [CrossRef]

90. Yu, Z.; Cai, Y.; Qin, W.; Lin, J.; Qiu, J. Polymyxin E Induces Rapid Paenibacillus Polymyxa Death by Damaging Cell Membrane while $\mathrm{Ca}^{2+}$ can Protect Cells from Damage. PLoS ONE 2015, 10, e0135198. [CrossRef]

91. Deris, Z.Z.; Akter, J.; Sivanesan, S.; Roberts, K.D.; Thompson, P.E.; Nation, R.L.; Li, J.; Velkov, T. A secondary mode of action of polymyxins against Gram-negative bacteria involves the inhibition of NADH-quinone oxidoreductase activity. J. Antibiot. 2014, 67, 147-151. [CrossRef]

92. Yu, Z.; Zhu, Y.; Fu, J.; Qiu, J.; Yin, J. Enhanced NADH Metabolism Involves Colistin-Induced Killing of Bacillus Subtilis and Paenibacillus Polymyxa. Molecules 2019, 24, 387. [CrossRef]

93. Mortensen, N.P.; Fowlkes, J.D.; Sullivan, C.J.; Allison, D.P.; Larsen, N.B.; Molin, S.; Doktycz, M.J. Effects of colistin on surface ultrastructure and nanomechanics of Pseudomonas aeruginosa cells. Langmuir ACS J. Surf. Colloids 2009, 25, 3728-3733. [CrossRef]

94. McCoy, L.S.; Roberts, K.D.; Nation, R.L.; Thompson, P.E.; Velkov, T.; Li, J.; Tor, Y. Polymyxins and analogues bind to ribosomal RNA and interfere with eukaryotic translation in vitro. Chembiochem Eur. J. Chem. Biol. 2013, 14, 2083-2086. [CrossRef] [PubMed]

95. Koen, N.; Van Breda, S.V.; Loots, D.T. Elucidating the antimicrobial mechanisms of colistin sulfate on Mycobacterium tuberculosis using metabolomics. Tuberc. Edinb. Scotl. 2018, 111, 14-19. [CrossRef] [PubMed] 
96. Mogi, T.; Murase, Y.; Mori, M.; Shiomi, K.; Omura, S.; Paranagama, M.P.; Kita, K. Polymyxin B identified as an inhibitor of alternative NADH dehydrogenase and malate: Quinone oxidoreductase from the Gram-positive bacterium Mycobacterium smegmatis. J. Biochem. 2009, 146, 491-499. [CrossRef]

97. Bax, H.I.; De Steenwinkel, J.E.M.; Kate, M.T.T.; Van der Meijden, A.; Verbon, A.; Bakker-Woudenberg, I.A.J.M. Colistin as a potentiator of anti-TB drug activity against Mycobacterium tuberculosis. J. Antimicrob. Chemother. 2015, 70, 2828-2837. [CrossRef]

98. Lim, L.M.; Ly, N.; Anderson, D.; Yang, J.C.; Macander, L.; Jarkowski, A.; Forrest, A.; Bulitta, J.B.; Tsuji, B.T. Resurgence of Colistin: A Review of Resistance, Toxicity, Pharmacodynamics, and Dosing. Pharmacotherapy 2010, 30, 1279-1291. [CrossRef]

99. Olaitan, A.O.; Morand, S.; Rolain, J.-M. Mechanisms of polymyxin resistance: Acquired and intrinsic resistance in bacteria. Front. Microbiol. 2014, 5, 643. [CrossRef] [PubMed]

100. Huang, J.; Li, C.; Song, J.; Velkov, T.; Wang, L.; Zhu, Y.; Li, J. Regulating polymyxin resistance in Gram-negative bacteria: Roles of two-component systems PhoPQ and PmrAB. Future Microbiol. 2020, 15, 445-459. [CrossRef] [PubMed]

101. Macfarlane, E.L.; Kwasnicka, A.; Ochs, M.M.; Hancock, R.E. PhoP-PhoQ homologues in Pseudomonas aeruginosa regulate expression of the outer-membrane protein $\mathrm{OprH}$ and polymyxin B resistance. Mol. Microbiol. 1999, 34, 305-316. [CrossRef] [PubMed]

102. Park, S.-Y.; Groisman, E.A. Signal-specific temporal response by the Salmonella PhoP/PhoQ regulatory system. Mol. Microbiol. 2014, 91, 135-144. [CrossRef]

103. Jayol, A.; Nordmann, P.; Brink, A.; Poirel, L. Heteroresistance to colistin in Klebsiella pneumoniae associated with alterations in the PhoPQ regulatory system. Antimicrob. Agents Chemother. 2015, 59, 2780-2784. [CrossRef]

104. Cannatelli, A.; Giani, T.; D’Andrea, M.M.; Di Pilato, V.; Arena, F.; Conte, V.; Tryfinopoulou, K.; Vatopoulos, A.; Rossolini, G.M. COLGRIT Study Group mgrB inactivation is a common mechanism of colistin resistance in KPC-producing Klebsiella pneumoniae of clinical origin. Antimicrob. Agents Chemother. 2014, 58, 5696-5703. [CrossRef] [PubMed]

105. Haeili, M.; Javani, A.; Moradi, J.; Jafari, Z.; Feizabadi, M.M.; Babaei, E. mgrB Alterations Mediate Colistin Resistance in Klebsiella pneumoniae Isolates from Iran. Front. Microbiol. 2017, 8, 2470. [CrossRef] [PubMed]

106. Zhang, H.; Zhao, D.; Shi, Q.; Quan, J.; Li, X.; Yu, Y. mcr-1 Gene has no Effect on Colistin Resistance when it Coexists with Inactivated mgrB Gene in Klebsiella pneumoniae. Microb. Drug Resist. 2018, 24, 1117-1120. [CrossRef] [PubMed]

107. Zafer, M.M.; El-Mahallawy, H.A.; Abdulhak, A.; Amin, M.A.; Al-Agamy, M.H.; Radwan, H.H. Emergence of colistin resistance in multidrug-resistant Klebsiella pneumoniae and Escherichia coli strains isolated from cancer patients. Ann. Clin. Microbiol. Antimicrob. 2019, 18, 40. [CrossRef] [PubMed]

108. Borsa, B.A.; Demirci, M.; Gungordu-Dalar, Z.; Karabiyik, G.; Aygun, G.; Kucukbasmaci, O. Molecular Mechanisms of Colistin Resistance among Klebsiella pneumoniae Strains. Clin. Lab. 2019, 65. [CrossRef]

109. Kim, S.; Woo, J.H.; Kim, N.; Kim, M.H.; Kim, S.Y.; Son, J.H.; Moon, D.C.; Lim, S.-K.; Shin, M.; Lee, J.C. Characterization of Chromosome-Mediated Colistin Resistance in Escherichia coli Isolates from Livestock in Korea. Infect. Drug Resist. 2019, 12, 3291-3299. [CrossRef]

110. Gutu, A.D.; Sgambati, N.; Strasbourger, P.; Brannon, M.K.; Jacobs, M.A.; Haugen, E.; Kaul, R.K.; Johansen, H.K.; Høiby, N.; Moskowitz, S.M. Polymyxin resistance of Pseudomonas aeruginosa phoQ mutants is dependent on additional two-component regulatory systems. Antimicrob. Agents Chemother. 2013, 57, 2204-2215. [CrossRef]

111. Gunn, J.S. The Salmonella PmrAB regulon: Lipopolysaccharide modifications, antimicrobial peptide resistance and more. Trends Microbiol. 2008, 16, 284-290. [CrossRef]

112. Sato, T.; Shiraishi, T.; Hiyama, Y.; Honda, H.; Shinagawa, M.; Usui, M.; Kuronuma, K.; Masumori, N.; Takahashi, S.; Tamura, Y.; et al. Contribution of Novel Amino Acid Alterations in PmrA or PmrB to Colistin Resistance in mcr-Negative Escherichia coli Clinical Isolates, Including Major Multidrug-Resistant Lineages O25b:H4-ST131-H30Rx and Non-x. Antimicrob. Agents Chemother. 2018, 62. [CrossRef]

113. Hong, Y.-K.; Ko, K.S. PmrAB and PhoPQ Variants in Colistin-Resistant Enterobacter spp. Isolates in Korea. Curr. Microbiol. 2019, 76, 644-649. [CrossRef]

114. Lin, J.; Xu, C.; Fang, R.; Cao, J.; Zhang, X.; Zhao, Y.; Dong, G.; Sun, Y.; Zhou, T. Resistance and Heteroresistance to Colistin in Pseudomonas aeruginosa Isolates from Wenzhou, China. Antimicrob. Agents Chemother. 2019, 63. [CrossRef] [PubMed] 
115. Gerson, S.; Betts, J.W.; Lucaßen, K.; Nodari, C.S.; Wille, J.; Josten, M.; Göttig, S.; Nowak, J.; Stefanik, D.; Roca, I.; et al. Investigation of Novel pmrB and eptA Mutations in Isogenic Acinetobacter baumannii Isolates Associated with Colistin Resistance and Increased Virulence In Vivo. Antimicrob. Agents Chemother. 2019, 63. [CrossRef] [PubMed]

116. Moubareck, C.A.; Halat, D.H. Insights into Acinetobacter baumannii: A Review of Microbiological, Virulence, and Resistance Traits in a Threatening Nosocomial Pathogen. Antibiotics 2020, 9, 119. [CrossRef] [PubMed]

117. Carretero-Ledesma, M.; García-Quintanilla, M.; Martín-Peña, R.; Pulido, M.R.; Pachón, J.; McConnell, M.J. Phenotypic changes associated with Colistin resistance due to Lipopolysaccharide loss in Acinetobacter baumannii. Virulence 2018, 9, 930-942. [CrossRef] [PubMed]

118. Jasim, R.; Baker, M.A.; Zhu, Y.; Han, M.; Schneider-Futschik, E.K.; Hussein, M.; Hoyer, D.; Li, J.; Velkov, T. A Comparative Study of Outer Membrane Proteome between Paired Colistin-Susceptible and Extremely Colistin-Resistant Klebsiella pneumoniae Strains. ACS Infect. Dis. 2018, 4, 1692-1704. [CrossRef]

119. Kádár, B.; Kocsis, B.; Tóth, Á.; Kristóf, K.; Felsô, P.; Kocsis, B.; Böddi, K.; Szabó, D. Colistin resistance associated with outer membrane protein change in Klebsiella pneumoniae and Enterobacter asburiae. Acta Microbiol. Immunol. Hung. 2017, 64, 217-227. [CrossRef]

120. Velkov, T.; Soon, R.L.; Chong, P.L.; Huang, J.X.; Cooper, M.A.; Azad, M.A.K.; Baker, M.A.; Thompson, P.E.; Roberts, K.; Nation, R.L.; et al. Molecular basis for the increased polymyxin susceptibility of Klebsiella pneumoniae strains with under-acylated lipid A. Innate Immun. 2013, 19, 265-277. [CrossRef]

121. Anyanwu, M.U.; Jaja, I.F.; Nwobi, O.C. Occurrence and Characteristics of Mobile Colistin Resistance ( $m c r)$ Gene-Containing Isolates from the Environment: A Review. Int. J. Environ. Res. Public Health 2020, 17, 1028. [CrossRef]

122. Shen, Y.; Zhang, R.; Schwarz, S.; Wu, C.; Shen, J.; Walsh, T.R.; Wang, Y. Farm animals and aquaculture: Significant reservoirs of mobile colistin resistance genes. Environ. Microbiol. 2020. [CrossRef]

123. Liu, Y.-Y.; Wang, Y.; Walsh, T.R.; Yi, L.-X.; Zhang, R.; Spencer, J.; Doi, Y.; Tian, G.; Dong, B.; Huang, X.; et al. Emergence of plasmid-mediated colistin resistance mechanism $m c r-1$ in animals and human beings in China: A microbiological and molecular biological study. Lancet Infect. Dis. 2016, 16, 161-168. [CrossRef]

124. Schwarz, S.; Johnson, A.P. Transferable resistance to colistin: A new but old threat. J. Antimicrob. Chemother. 2016, 71, 2066-2070. [CrossRef] [PubMed]

125. Wang, C.; Feng, Y.; Liu, L.; Wei, L.; Kang, M.; Zong, Z. Identification of novel mobile colistin resistance gene mcr-10. Emerg. Microbes Infect. 2020, 9, 508-516. [CrossRef] [PubMed]

126. Gao, R.; Hu, Y.; Li, Z.; Sun, J.; Wang, Q.; Lin, J.; Ye, H.; Liu, F.; Srinivas, S.; Li, D.; et al. Dissemination and Mechanism for the mcr-1 Colistin Resistance. PLoS Pathog. 2016, 12, e1005957. [CrossRef] [PubMed]

127. Khondker, A.; Dhaliwal, A.K.; Saem, S.; Mahmood, A.; Fradin, C.; Moran-Mirabal, J.; Rheinstädter, M.C. Membrane charge and lipid packing determine polymyxin-induced membrane damage. Commun. Biol. 2019, 2, 1-11. [CrossRef]

128. Xavier, B.B.; Lammens, C.; Ruhal, R.; Kumar-Singh, S.; Butaye, P.; Goossens, H.; Malhotra-Kumar, S. Identification of a novel plasmid-mediated colistin-resistance gene, mcr-2, in Escherichia coli, Belgium, June 2016. Euro Surveill. Bull. Eur. Sur. Mal. Transm. Eur. Commun. Dis. Bull. 2016, 21. [CrossRef]

129. Yin, W.; Li, H.; Shen, Y.; Liu, Z.; Wang, S.; Shen, Z.; Zhang, R.; Walsh, T.R.; Shen, J.; Wang, Y. Novel Plasmid-Mediated Colistin Resistance Gene mcr-3 in Escherichia coli. mBio 2017, 8. [CrossRef]

130. Carattoli, A.; Villa, L.; Feudi, C.; Curcio, L.; Orsini, S.; Luppi, A.; Pezzotti, G.; Magistrali,C.F. Novel plasmid-mediated colistin resistance mcr-4 gene in Salmonella and Escherichia coli, Italy 2013, Spain and Belgium, 2015 to 2016. Euro Surveill. Bull. Eur. Sur. Mal. Transm. Eur. Commun. Dis. Bull. 2017, 22. [CrossRef]

131. Borowiak, M.; Fischer, J.; Hammerl, J.A.; Hendriksen, R.S.; Szabo, I.; Malorny, B. Identification of a novel transposon-associated phosphoethanolamine transferase gene, $m c r-5$, conferring colistin resistance in d-tartrate fermenting Salmonella enterica subsp. enterica serovar Paratyphi, B. J. Antimicrob. Chemother. 2017, 72, 3317-3324. [CrossRef]

132. AbuOun, M.; Stubberfield, E.J.; Duggett, N.A.; Kirchner, M.; Dormer, L.; Nunez-Garcia, J.; Randall, L.P.; Lemma, F.; Crook, D.W.; Teale, C.; et al. mcr-1 and mcr-2 (mcr-6.1) variant genes identified in Moraxella species isolated from pigs in Great Britain from 2014 to 2015. J. Antimicrob. Chemother. 2018, 73, 2904. [CrossRef]

133. Yang, Y.-Q.; Li, Y.-X.; Lei, C.-W.; Zhang, A.-Y.; Wang, H.-N. Novel plasmid-mediated colistin resistance gene mcr-7.1 in Klebsiella pneumoniae. J. Antimicrob. Chemother. 2018, 73, 1791-1795. [CrossRef] 
134. Wang, X.; Wang, Y.; Zhou, Y.; Li, J.; Yin, W.; Wang, S.; Zhang, S.; Shen, J.; Shen, Z.; Wang, Y. Emergence of a novel mobile colistin resistance gene, $m c r-8$, in NDM-producing Klebsiella pneumoniae. Emerg. Microbes Infect. 2018, 7, 1-9. [CrossRef] [PubMed]

135. Carroll, L.M.; Gaballa, A.; Guldimann, C.; Sullivan, G.; Henderson, L.O.; Wiedmann, M. Identification of Novel Mobilized Colistin Resistance Gene $m c r-9$ in a Multidrug-Resistant, Colistin-Susceptible Salmonella enterica Serotype Typhimurium Isolate. mBio 2019, 10. [CrossRef] [PubMed]

136. Halat, D.H.; Moubareck, C.A. The Current Burden of Carbapenemases: Review of Significant Properties and Dissemination among Gram-Negative Bacteria. Antibiotics 2020, 9, 186. [CrossRef] [PubMed]

137. Liu, B.-T.; Song, F.-J.; Zou, M.; Hao, Z.-H.; Shan, H. Emergence of Colistin Resistance Gene mcr-1 in Cronobacter sakazakii Producing NDM-9 and in Escherichia coli from the Same Animal. Antimicrob. Agents Chemother. 2017, 61. [CrossRef]

138. Snesrud, E.; He, S.; Chandler, M.; Dekker, J.P.; Hickman, A.B.; McGann, P.; Dyda, F. A Model for Transposition of the Colistin Resistance Gene mor-1 by ISApl1. Antimicrob. Agents Chemother. 2016, 60, 6973-6976. [CrossRef]

139. Poirel, L.; Kieffer, N.; Brink, A.; Coetze, J.; Jayol, A.; Nordmann, P. Genetic Features of mcr-1-Producing Colistin-Resistant Escherichia coli Isolates in South Africa. Antimicrob. Agents Chemother. 2016, 60, 4394-4397. [CrossRef]

140. Li, R.; Xie, M.; Zhang, J.; Yang, Z.; Liu, L.; Liu, X.; Zheng, Z.; Chan, E.W.-C.; Chen, S. Genetic characterization of $m c r-1$-bearing plasmids to depict molecular mechanisms underlying dissemination of the colistin resistance determinant. J. Antimicrob. Chemother. 2017, 72, 393-401. [CrossRef]

141. Snesrud, E.; McGann, P.; Chandler, M. The Birth and Demise of the ISApl1-mcr-1-ISApl1 Composite Transposon: The Vehicle for Transferable Colistin Resistance. mBio 2018, 9. [CrossRef]

142. Zurfluh, K.; Tasara, T.; Poirel, L.; Nordmann, P.; Stephan, R. Draft Genome Sequence of Escherichia coli S51, a Chicken Isolate Harboring a Chromosomally Encoded mcr-1 Gene. Genome Announc. 2016, 4. [CrossRef]

143. Sun, J.; Zhang, H.; Liu, Y.-H.; Feng, Y. Towards Understanding mcr-Like Colistin Resistance. Trends Microbiol. 2018, 26, 794-808. [CrossRef]

144. Sun, J.; Xu, Y.; Gao, R.; Lin, J.; Wei, W.; Srinivas, S.; Li, D.; Yang, R.-S.; Li, X.-P.; Liao, X.-P.; et al. Deciphering mcr-2 Colistin Resistance. mBio 2017, 8. [CrossRef] [PubMed]

145. Prim, N.; Turbau, M.; Rivera, A.; Rodríguez-Navarro, J.; Coll, P.; Mirelis, B. Prevalence of colistin resistance in clinical isolates of Enterobacteriaceae: A four-year cross-sectional study. J. Infect. 2017, 75, 493-498. [CrossRef] [PubMed]

146. Peter, S.; Bezdan, D.; Oberhettinger, P.; Vogel, W.; Dörfel, D.; Dick, J.; Marschal, M.; Liese, J.; Weidenmaier, C.; Autenrieth, I.; et al. Whole-genome sequencing enabling the detection of a colistin-resistant hypermutating Citrobacter werkmanii strain harbouring a novel metallo- $\beta$-lactamase VIM-48. Int. J. Antimicrob. Agents 2018, 51, 867-874. [CrossRef] [PubMed]

147. Cheng, H.-Y.; Chen, Y.-F.; Peng, H.-L. Molecular characterization of the PhoPQ-PmrD-PmrAB mediated pathway regulating polymyxin B resistance in Klebsiella pneumoniae CG43. J. Biomed. Sci. 2010, 17, 60. [CrossRef]

148. Formosa, C.; Herold, M.; Vidaillac, C.; Duval, R.E.; Dague, E. Unravelling of a mechanism of resistance to colistin in Klebsiella pneumoniae using atomic force microscopy. J. Antimicrob. Chemother. 2015, 70, 2261-2270. [CrossRef]

149. Srinivasan, V.B.; Rajamohan, G. KpnEF, a new member of the Klebsiella pneumoniae cell envelope stress response regulon, is an SMR-type efflux pump involved in broad-spectrum antimicrobial resistance. Antimicrob. Agents Chemother. 2013, 57, 4449-4462. [CrossRef]

150. Moosavian, M.; Emam, N. The first report of emerging mobilized colistin-resistance ( $m c r)$ genes and ERIC-PCR typing in Escherichia coli and Klebsiella pneumoniae clinical isolates in southwest Iran. Infect. Drug Resist. 2019, 12, 1001-1010. [CrossRef]

151. Jo, H.; Jeong, E.Y.; Jeon, J.; Ban, C. Structural insights into Escherichia coli polymyxin B resistance protein D with X-ray crystallography and small-angle X-ray scattering. BMC Struct. Biol. 2014, 14, 24. [CrossRef]

152. Moon, K.; Gottesman, S. A PhoQ/P-regulated small RNA regulates sensitivity of Escherichia coli to antimicrobial peptides. Mol. Microbiol. 2009, 74, 1314-1330. [CrossRef]

153. Vounba, P.; Rhouma, M.; Arsenault, J.; Alambédji, R.B.; Fravalo, P.; Fairbrother, J.M. Prevalence of colistin resistance and $m c r-1 / m c r-2$ genes in extended-spectrum $\beta$-lactamase/AmpC-producing Escherichia coli isolated from chickens in Canada, Senegal and Vietnam. J. Glob. Antimicrob. Resist. 2019, 19, 222-227. [CrossRef] 
154. García, V.; García-Meniño, I.; Mora, A.; Flament-Simon, S.C.; Díaz-Jiménez, D.; Blanco, J.E.; Alonso, M.P.; Blanco, J. Co-occurrence of $m c r-1, m c r-4$ and $m c r-5$ genes in multidrug-resistant ST10 Enterotoxigenic and Shiga toxin-producing Escherichia coli in Spain (2006-2017). Int. J. Antimicrob. Agents 2018, 52, 104-108. [CrossRef] [PubMed]

155. Gunn, J.S.; Miller, S.I. PhoP-PhoQ activates transcription of $p m r$ AB, encoding a two-component regulatory system involved in Salmonella typhimurium antimicrobial peptide resistance. J. Bacteriol. 1996, 178, 6857-6864. [CrossRef] [PubMed]

156. Quesada, A.; Porrero, M.C.; Téllez, S.; Palomo, G.; García, M.; Domínguez, L. Polymorphism of genes encoding PmrAB in colistin-resistant strains of Escherichia coli and Salmonella enterica isolated from poultry and swine. J. Antimicrob. Chemother. 2015, 70, 71-74. [CrossRef]

157. Sheng, X.; Wang, W.; Chen, L.; Zhang, H.; Zhang, Y.; Xu, S.; Xu, H.; Huang, X. Mig-14 may contribute to Salmonella enterica serovar Typhi resistance to polymyxin B by decreasing the permeability of the outer-membrane and promoting the formation of biofilm. Int. J. Med. Microbiol. 2019, 309, 143-150. [CrossRef] [PubMed]

158. Borowiak, M.; Hammerl, J.A.; Deneke, C.; Fischer, J.; Szabo, I.; Malorny, B. Characterization of mcr-5-Harboring Salmonella enterica subsp. enterica Serovar Typhimurium Isolates from Animal and Food Origin in Germany. Antimicrob. Agents Chemother. 2019, 63. [CrossRef]

159. Miller, A.K.; Brannon, M.K.; Stevens, L.; Johansen, H.K.; Selgrade, S.E.; Miller, S.I.; Høiby, N.; Moskowitz, S.M. PhoQ mutations promote lipid A modification and polymyxin resistance of Pseudomonas aeruginosa found in colistin-treated cystic fibrosis patients. Antimicrob. Agents Chemother. 2011, 55, 5761-5769. [CrossRef]

160. Barrow, K.; Kwon, D.H. Alterations in two-component regulatory systems of phoPQ and pmrAB are associated with polymyxin B resistance in clinical isolates of Pseudomonas aeruginosa. Antimicrob. Agents Chemother. 2009, 53, 5150-5154. [CrossRef]

161. Fernández, L.; Jenssen, H.; Bains, M.; Wiegand, I.; Gooderham, W.J.; Hancock, R.E.W. The two-component system CprRS senses cationic peptides and triggers adaptive resistance in Pseudomonas aeruginosa independently of ParRS. Antimicrob. Agents Chemother. 2012, 56, 6212-6222. [CrossRef]

162. Goli, H.R.; Nahaei, M.R.; Rezaee, M.A.; Hasani, A.; Kafil, H.S.; Aghazadeh, M. Emergence of colistin resistant Pseudomonas aeruginosa at Tabriz hospitals, Iran. Iran. J. Microbiol. 2016, 8, 62-69.

163. Puja, H.; Bolard, A.; Noguès, A.; Plésiat, P.; Jeannot, K. The Efflux Pump MexXY/OprM Contributes to the Tolerance and Acquired Resistance of Pseudomonas aeruginosa to Colistin. Antimicrob. Agents Chemother. 2020, 64. [CrossRef]

164. Han, M.-L.; Velkov, T.; Zhu, Y.; Roberts, K.D.; Le Brun, A.P.; Chow, S.H.; Gutu, A.D.; Moskowitz, S.M.; Shen, H.-H.; Li, J. Polymyxin-Induced Lipid A Deacylation in Pseudomonas aeruginosa Perturbs Polymyxin Penetration and Confers High-Level Resistance. ACS Chem. Biol. 2018, 13, 121-130. [CrossRef] [PubMed]

165. Snesrud, E.; Maybank, R.; Kwak, Y.I.; Jones, A.R.; Hinkle, M.K.; McGann, P. Chromosomally Encoded mcr-5 in Colistin-Nonsusceptible Pseudomonas aeruginosa. Antimicrob. Agents Chemother. 2018, 62. [CrossRef]

166. Hameed, F.; Khan, M.A.; Muhammad, H.; Sarwar, T.; Bilal, H.; Rehman, T.U. Plasmid-mediated mcr-1 gene in Acinetobacter baumannii and Pseudomonas aeruginosa: First report from Pakistan. Rev. Soc. Bras. Med. Trop. 2019, 52, e20190237. [CrossRef] [PubMed]

167. Chin, C.-Y.; Gregg, K.A.; Napier, B.A.; Ernst, R.K.; Weiss, D.S. A PmrB-Regulated Deacetylase Required for Lipid A Modification and Polymyxin Resistance in Acinetobacter baumannii. Antimicrob. Agents Chemother. 2015, 59, 7911-7914. [CrossRef] [PubMed]

168. Lin, M.-F.; Lin, Y.-Y.; Lan, C.-Y. Contribution of EmrAB efflux pumps to colistin resistance in Acinetobacter baumannii. J. Microbiol. Seoul Korea 2017, 55, 130-136. [CrossRef] [PubMed]

169. Ma, F.; Shen, C.; Zheng, X.; Liu, Y.; Chen, H.; Zhong, L.; Liang, Y.; Liao, K.; Xia, Y.; Tian, G.-B.; et al. Identification of a Novel Plasmid Carrying mor-4.3 in an Acinetobacter baumannii Strain in China. Antimicrob. Agents Chemother. 2019, 63. [CrossRef]

170. Mularski, A.; Wilksch, J.; Hanssen, E.; Li, J.; Tomita, T.; Pidot, S.J.; Stinear, T.; Separovic, F.; Strugnell, D. A nanomechanical study of the effects of colistin on the Klebsiella pneumoniae AJ218 capsule. Eur. Biophys. J. 2017, 46, 351-361. [CrossRef]

171. Llobet, E.; Tomás, J.M.; Bengoechea, J.A. Capsule polysaccharide is a bacterial decoy for antimicrobial peptides. Microbiol. Read. Engl. 2008, 154, 3877-3886. [CrossRef]

172. Poirel, L.; Nordmann, P. Emerging plasmid-encoded colistin resistance: The animal world as the culprit? J. Antimicrob. Chemother. 2016, 71, 2326-2327. [CrossRef] 
173. Wang, Y.; Tian, G.-B.; Zhang, R.; Shen, Y.; Tyrrell, J.M.; Huang, X.; Zhou, H.; Lei, L.; Li, H.-Y.; Doi, Y.; et al. Prevalence, risk factors, outcomes, and molecular epidemiology of mcr-1-positive Enterobacteriaceae in patients and healthy adults from China: An epidemiological and clinical study. Lancet Infect. Dis. 2017, 17, 390-399. [CrossRef]

174. Caselli, E.; D'Accolti, M.; Soffritti, I.; Piffanelli, M.; Mazzacane, S. Spread of mcr-1-Driven Colistin Resistance on Hospital Surfaces, Italy. Emerg. Infect. Dis. 2018, 24, 1752-1753. [CrossRef] [PubMed]

175. Yoon, E.J.; Hong, J.S.; Yang, J.W.; Lee, K.J.; Lee, H.; Jeong, S.H. Detection of $m c r-1$ Plasmids in Enterobacteriaceae Isolates from Human Specimens: Comparison with those in Escherichia coli Isolates from Livestock in Korea. Ann. Lab. Med. 2018, 38, 555-562. [CrossRef] [PubMed]

176. Liu, B.-T.; Li, X.; Zhang, Q.; Shan, H.; Zou, M.; Song, F.-J. Colistin-Resistant mcr-Positive Enterobacteriaceae in Fresh Vegetables, an Increasing Infectious Threat in China. Int. J. Antimicrob. Agents 2019, 54, 89-94. [CrossRef] [PubMed]

177. Ahmed, Z.S.; Elshafiee, E.A.; Khalefa, H.S.; Kadry, M.; Hamza, D.A. Evidence of colistin resistance genes (mcr-1 and mcr-2) in wild birds and its public health implication in Egypt. Antimicrob. Resist. Infect. Control 2019, 8, 197. [CrossRef] [PubMed]

178. Shen, C.; Feng, S.; Chen, H.; Dai, M.; Paterson, D.L.; Zheng, X.; Wu, X.; Zhong, L.-L.; Liu, Y.; Xia, Y.; et al. Transmission of mcr-1-Producing Multidrug-resistant Enterobacteriaceae in Public Transportation in Guangzhou, China. Clin. Infect. Dis. Off. Publ. Infect. Dis. Soc. Am. 2018, 67, S217-S224. [CrossRef]

179. Hassen, B.; Saloua, B.; Abbassi, M.S.; Ruiz-Ripa, L.; Mama, O.M.; Hassen, A.; Hammami, S.; Torres, C. mcr-1 encoding colistin resistance in CTX-M-1/CTX-M-15- producing Escherichia coli isolates of bovine and caprine origins in Tunisia. First report of CTX-M-15-ST394/D E. coli from goats. Comp. Immunol. Microbiol. Infect. Dis. 2019, 67, 101366. [CrossRef]

180. Dalmolin, T.V.; Martins, A.F.; Zavascki, A.P.; De Lima-Morales, D.; Barth, A.L. Acquisition of the $m c r-1$ gene by a high-risk clone of KPC-2-producing Klebsiella pneumoniae ST437/CC258, Brazil. Diagn. Microbiol. Infect. Dis. 2018, 90, 132-133. [CrossRef]

181. Caltagirone, M.; Nucleo, E.; Spalla, M.; Zara, F.; Novazzi, F.; Marchetti, V.M.; Piazza, A.; Bitar, I.; De Cicco, M.; Paolucci, S.; et al. Occurrence of Extended Spectrum $\beta$-Lactamases, KPC-Type, and mcr-1.2-Producing Enterobacteriaceae from Wells, River Water, and Wastewater Treatment Plants in Oltrepò Pavese Area, Northern Italy. Front. Microbiol. 2017, 8, 2232. [CrossRef]

182. Moubareck, C.A.; Mouftah, S.F.; Pál, T.; Ghazawi, A.; Halat, D.H.; Nabi, A.; AlSharhan, M.A.; AlDeesi, Z.O.; Peters, C.C.; Celiloglu, H.; et al. Clonal emergence of Klebsiella pneumoniae ST14 co-producing OXA-48-type and NDM carbapenemases with high rate of colistin resistance in Dubai, United Arab Emirates. Int. J. Antimicrob. Agents 2018, 52, 90-95. [CrossRef] [PubMed]

183. Orsi, T.D.; Neto, L.V.P.; Martins, R.C.R.; Levin, A.S.; Costa, S.F. Polymyxin-resistant Pseudomonas aeruginosa assigned as ST245: First report in an intensive care unit in São Paulo, Brazil. J. Glob. Antimicrob. Resist. 2019, 16, 147-149. [CrossRef] [PubMed]

184. Lee, J.-Y.; Ko, K.S. Mutations and expression of PmrAB and PhoPQ related with colistin resistance in Pseudomonas aeruginosa clinical isolates. Diagn. Microbiol. Infect. Dis. 2014, 78, 271-276. [CrossRef] [PubMed]

185. Abraham, N.; Kwon, D.H. A single amino acid substitution in PmrB is associated with polymyxin B resistance in clinical isolate of Pseudomonas aeruginosa. FEMS Microbiol. Lett. 2009, 298, 249-254. [CrossRef] [PubMed]

186. Owusu-Anim, D.; Kwon, D.H. Differential Role of Two-Component Regulatory Systems ( $p h o P Q$ and pmrAB) in Polymyxin B Susceptibility of Pseudomonas aeruginosa. Adv. Microbiol. 2012, 2. [CrossRef]

187. Muller, C.; Plésiat, P.; Jeannot, K. A two-component regulatory system interconnects resistance to polymyxins, aminoglycosides, fluoroquinolones, and $\beta$-lactams in Pseudomonas aeruginosa. Antimicrob. Agents Chemother. 2011, 55, 1211-1221. [CrossRef] [PubMed]

188. Yokota, S.-I.; Hakamada, H.; Yamamoto, S.; Sato, T.; Shiraishi, T.; Shinagawa, M.; Takahashi, S. Release of large amounts of lipopolysaccharides from Pseudomonas aeruginosa cells reduces their susceptibility to colistin. Int. J. Antimicrob. Agents 2018, 51, 888-896. [CrossRef] [PubMed]

189. Lee, Y.-L.; Lu, M.-C.; Shao, P.-L.; Lu, P.-L.; Chen, Y.-H.; Cheng, S.-H.; Ko, W.-C.; Lin, C.-Y.; Wu, T.-S.; Yen, M.-Y.; et al. Nationwide surveillance of antimicrobial resistance among clinically important Gram-negative bacteria, with an emphasis on carbapenems and colistin: Results from the Surveillance of Multicenter Antimicrobial Resistance in Taiwan (SMART) in 2018. Int. J. Antimicrob. Agents 2019, 54, 318-328. [CrossRef] 
190. Katchanov, J.; Asar, L.; Klupp, E.-M.; Both, A.; Rothe, C.; König, C.; Rohde, H.; Kluge, S.; Maurer, F.P. Carbapenem-resistant Gram-negative pathogens in a German university medical center: Prevalence, clinical implications and the role of novel $\beta$-lactam/ $\beta$-lactamase inhibitor combinations. PLOS ONE 2018, 13, e0195757. [CrossRef]

191. Del Barrio-Tofiño, E.; Zamorano, L.; Cortes-Lara, S.; López-Causapé, C.; Sánchez-Diener, I.; Cabot, G.; Bou, G.; Martínez-Martínez, L.; Oliver, A. GEMARA-SEIMC/REIPI Pseudomonas study Group Spanish nationwide survey on Pseudomonas aeruginosa antimicrobial resistance mechanisms and epidemiology. J. Antimicrob. Chemother. 2019, 74, 1825-1835. [CrossRef]

192. Wi, Y.M.; Choi, J.-Y.; Lee, J.-Y.; Kang, C.-I.; Chung, D.R.; Peck, K.R.; Song, J.-H.; Ko, K.S. Emergence of colistin resistance in Pseudomonas aeruginosa ST235 clone in South Korea. Int. J. Antimicrob. Agents 2017, 49, 767-769. [CrossRef]

193. Tunyapanit, W.; Pruekprasert, P.; Laoprasopwattana, K.; Chelae, S. In vitro activity of colistin against multidrug-resistant Pseudomonas aeruginosa isolates from patients in Songklanagarind Hospital, Thailand. Southeast Asian J. Trop. Med. Public Health 2013, 44, 273-280.

194. Moubareck, C.A.; Halat, D.H.; Akkawi, C.; Nabi, A.; AlSharhan, M.A.; AlDeesi, Z.O.; Peters, C.C.; Celiloglu, H.; Sarkis, D.K. Role of outer membrane permeability, efflux mechanism, and carbapenemases in carbapenem-nonsusceptible Pseudomonas aeruginosa from Dubai hospitals: Results of the first cross-sectional survey. Int. J. Infect. Dis. IJID Off. Publ. Int. Soc. Infect. Dis. 2019, 84, 143-150. [CrossRef] [PubMed]

195. Garg, A.; Garg, J.; Kumar, S.; Bhattacharya, A.; Agarwal, S.; Upadhyay, G.C. Molecular epidemiology \& therapeutic options of carbapenem-resistant Gram-negative bacteria. Indian J. Med. Res. 2019, 149, 285-289. [CrossRef] [PubMed]

196. Giani, T.; Arena, F.; Pollini, S.; Di Pilato, V.; D’Andrea, M.M.; De Angelis, L.H.; Bassetti, M.; Rossolini, G.M. Pseudomonas aeruginosa Working Group Italian nationwide survey on Pseudomonas aeruginosa from invasive infections: Activity of ceftolozane/tazobactam and comparators, and molecular epidemiology of carbapenemase producers. J. Antimicrob. Chemother. 2018, 73, 664-671. [CrossRef] [PubMed]

197. Trebosc, V.; Gartenmann, S.; Tötzl, M.; Lucchini, V.; Schellhorn, B.; Pieren, M.; Lociuro, S.; Gitzinger, M.; Tigges, M.; Bumann, D.; et al. Dissecting Colistin Resistance Mechanisms in Extensively Drug-Resistant Acinetobacter baumannii Clinical Isolates. mBio 2019, 10. [CrossRef] [PubMed]

198. Lima, W.G.; Alves, M.C.; Cruz, W.S.; Paiva, M.C. Chromosomally encoded and plasmid-mediated polymyxins resistance in Acinetobacter baumannii: A huge public health threat. Eur. J. Clin. Microbiol. Infect. Dis. Off. Publ. Eur. Soc. Clin. Microbiol. 2018, 37, 1009-1019. [CrossRef] [PubMed]

199. Moffatt, J.H.; Harper, M.; Adler, B.; Nation, R.L.; Li, J.; Boyce, J.D. Insertion sequence ISAba11 is involved in colistin resistance and loss of lipopolysaccharide in Acinetobacter baumannii. Antimicrob. Agents Chemother. 2011, 55, 3022-3024. [CrossRef]

200. Moffatt, J.H.; Harper, M.; Harrison, P.; Hale, J.D.F.; Vinogradov, E.; Seemann, T.; Henry, R.; Crane, B.; St Michael, F.; Cox, A.D.; et al. Colistin resistance in Acinetobacter baumannii is mediated by complete loss of lipopolysaccharide production. Antimicrob. Agents Chemother. 2010, 54, 4971-4977. [CrossRef]

201. Charretier, Y.; Diene, S.M.; Baud, D.; Chatellier, S.; Santiago-Allexant, E.; Van Belkum, A.; Guigon, G.; Schrenzel, J. Colistin Heteroresistance and Involvement of the PmrAB Regulatory System in Acinetobacter baumannii. Antimicrob. Agents Chemother. 2018, 62. [CrossRef]

202. Whitfield, C.; Trent, M.S. Biosynthesis and export of bacterial lipopolysaccharides. Annu. Rev. Biochem. 2014, 83, 99-128. [CrossRef]

203. Lucas, D.D.; Crane, B.; Wright, A.; Han, M.-L.; Moffatt, J.; Bulach, D.; Gladman, S.L.; Powell, D.; Aranda, J.; Seemann, T.; et al. Emergence of High-Level Colistin Resistance in an Acinetobacter baumannii Clinical Isolate Mediated by Inactivation of the Global Regulator H-NS. Antimicrob. Agents Chemother. 2018, 62. [CrossRef]

204. Gelbíčová, T.; Baráková, A.; Florianová, M.; Karpíšková, R. Detection of colistin-resistant Acinetobacter baumannii with the mcr-4 gene. Klin. Mikrobiol. Infekcni Lek. 2019, 25, 4-6.

205. Martins-Sorenson, N.; Snesrud, E.; Xavier, D.E.; Cacci, L.C.; Iavarone, A.T.; McGann, P.; Riley, L.W.; Moreira, B.M. A novel plasmid-encoded $m c r-4.3$ gene in a colistin-resistant Acinetobacter baumannii clinical strain. J. Antimicrob. Chemother. 2020, 75, 60-64. [CrossRef] [PubMed]

206. Velkov, T.; Roberts, K.D.; Nation, R.L.; Wang, J.; Thompson, P.E.; Li, J. Teaching "old" polymyxins new tricks: New-generation lipopeptides targeting gram-negative "superbugs". ACS Chem. Biol. 2014, 9, 1172-1177. [CrossRef] 
207. Yu, S.; Wang, S.; Zou, P.; Chai, G.; Lin, Y.-W.; Velkov, T.; Li, J.; Pan, W.; Zhou, Q.T. Inhalable liposomal powder formulations for co-delivery of synergistic ciprofloxacin and colistin against multi-drug resistant gram-negative lung infections. Int. J. Pharm. 2020, 575, 118915. [CrossRef]

208. Dubashynskaya, N.V.; Skorik, Y.A. Polymyxin Delivery Systems: Recent Advances and Challenges. Pharmaceuticals 2020, 13, 83. [CrossRef] [PubMed]

209. Obuobi, S.; Voo, Z.X.; Low, M.W.; Czarny, B.; Selvarajan, V.; Ibrahim, N.L.; Yang, Y.Y.; Ee, P.L.R. Phenylboronic Acid Functionalized Polycarbonate Hydrogels for Controlled Release of Polymyxin B in Pseudomonas aeruginosa Infected Burn Wounds. Adv. Healthc. Mater. 2018, 7, 1701388. [CrossRef]

210. Dillon, C.; Hughes, H.; O’Reilly, N.J.; McLoughlin, P. Formulation and characterisation of dissolving microneedles for the transdermal delivery of therapeutic peptides. Int. J. Pharm. 2017, 526, 125-136. [CrossRef]

211. Dillon, C.; Hughes, H.; O’Reilly, N.J.; Allender, C.J.; Barrow, D.A.; McLoughlin, P. Dissolving microneedle based transdermal delivery of therapeutic peptide analogues. Int. J. Pharm. 2019, 565, 9-19. [CrossRef]

212. Bartelds, R.; Nematollahi, M.H.; Pols, T.; Stuart, M.C.A.; Pardakhty, A.; Asadikaram, G.; Poolman, B. Niosomes, an alternative for liposomal delivery. PLoS ONE 2018, 13, e0194179. [CrossRef]

213. Chauhan, M.K.; Bhatt, N. Bioavailability Enhancement of Polymyxin B with Novel Drug Delivery: Development and Optimization Using Quality-by-Design Approach. J. Pharm. Sci. 2019, 108, 1521-1528. [CrossRef]

214. Hussein, M.; Schneider-Futschik, E.K.; Paulin, O.K.A.; Allobawi, R.; Crawford, S.; Zhou, Q.T.; Hanif, A.; Baker, M.; Zhu, Y.; Li, J.; et al. Effective Strategy Targeting Polymyxin-Resistant Gram-Negative Pathogens: Polymyxin B in Combination with the Selective Serotonin Reuptake Inhibitor Sertraline. ACS Infect. Dis. 2020, 6, 1436-1450. [CrossRef] [PubMed]

215. Zhang, Y.; Wang, X.; Li, X.; Dong, L.; Hu, X.; Nie, T.; Lu, Y.; Lu, X.; Pang, J.; Li, G.; et al. Synergistic Effect of Colistin Combined with PFK-158 against Colistin-Resistant Enterobacteriaceae. Antimicrob. Agents Chemother. 2019, 63. [CrossRef] [PubMed]

216. Loose, M.; Naber, K.G.; Hu, Y.; Coates, A.; Wagenlehner, F.M.E. Urinary bactericidal activity of colistin and azidothymidine combinations against mcr-1-positive colistin-resistant Escherichia coli. Int. J. Antimicrob. Agents 2019, 54, 55-61. [CrossRef] [PubMed]

217. Hussein, M.; Han, M.-L.; Zhu, Y.; Schneider-Futschik, E.K.; Hu, X.; Zhou, Q.T.; Lin, Y.-W.; Anderson, D.; Creek, D.J.; Hoyer, D.; et al. Mechanistic Insights from Global Metabolomics Studies into Synergistic Bactericidal Effect of a Polymyxin B Combination with Tamoxifen against Cystic Fibrosis MDR Pseudomonas aeruginosa. Comput. Struct. Biotechnol. J. 2018, 16, 587-599. [CrossRef] [PubMed]

218. Geitani, R.; Moubareck, C.A.; Touqui, L.; Sarkis, D.K. Cationic antimicrobial peptides: Alternatives and/or adjuvants to antibiotics active against methicillin-resistant Staphylococcus aureus and multidrug-resistant Pseudomonas aeruginosa. BMC Microbiol. 2019, 19, 54. [CrossRef] [PubMed]

219. Dosler, S.; Karaaslan, E. Inhibition and destruction of Pseudomonas aeruginosa biofilms by antibiotics and antimicrobial peptides. Peptides 2014, 62, 32-37. [CrossRef]

220. Frecer, V.; Ho, B.; Ding, J.L. De novo design of potent antimicrobial peptides. Antimicrob. Agents Chemother. 2004, 48, 3349-3357. [CrossRef]

221. Brown, P.; Abbott, E.; Abdulle, O.; Boakes, S.; Coleman, S.; Divall, N.; Duperchy, E.; Moss, S.; Rivers, D.; Simonovic, M.; et al. Design of next Generation Polymyxins with Lower Toxicity: The Discovery of SPR206. ACS Infect. Dis. 2019, 5, 1645-1656. [CrossRef]

(C) 2020 by the author. Licensee MDPI, Basel, Switzerland. This article is an open access article distributed under the terms and conditions of the Creative Commons Attribution (CC BY) license (http://creativecommons.org/licenses/by/4.0/). 